\title{
Chương trình, giảng viên và tài liệu Việt Nam Học 2019
}

Faculty of Vietnamese Studies

09 April 2019

University of Social Sciences and Humanities

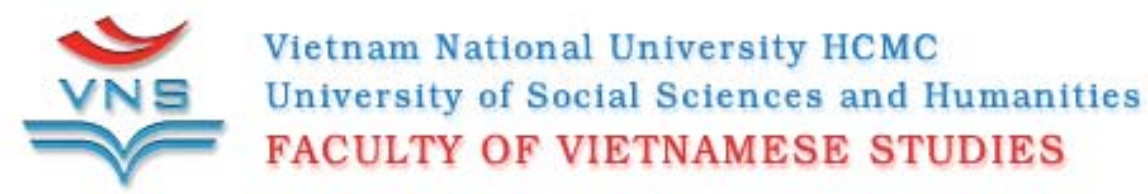

Vietnam National University HCMC

https://lib.hcmussh.edu.vn/Resources/Docs/SubDomain/lib/Tai\%20lieu\%20mon\%20hoc/2019/ KhoaVietNamhoc2019_DH.pdf 


\begin{tabular}{|c|c|c|c|c|c|c|c|c|}
\hline STT & TÊN HỌC PHẦ & GIẢNG VIÊN & LOẠI & TÀI LIỆU HỌC TẬP - THAM KHẢO & $\begin{array}{l}\text { MÔN } \\
\text { LOẠI }\end{array}$ & KHO & $\begin{array}{c}\text { GHI CHÚ } \\
\text { SỐ HÓA }\end{array}$ & $\begin{array}{c}\text { GHI CHÚ } \\
\text { KHÁC }\end{array}$ \\
\hline 1 & Tiếng Việt trung cấp - đọc & Nguyễn Thanh Phong & GT & Giáo trình tiếng Việt Trung Cấp-Đọc & & & $\mathrm{C}$ & GV cung cấp \\
\hline 2 & Tiếng Việt trung cấp - đọc & Nguyễn Thanh Phong & $\mathrm{TKC}$ & Punctuation & & & $\mathrm{C}$ & Khoa có \\
\hline 3 & Tiếng Việt trung cấp: nghe & Bùi Thị Phương Chi & GT & $\begin{array}{l}\text { Giáo trình Luyện nghe : giáo trình lưu hành nội bộ / } \\
\text { Bùi Thị Phương Chi, Dương Thị Thu Hương, } \\
\text { Nguyễn Vân Phổ }\end{array}$ & & & $\mathrm{C}$ & Khoa có \\
\hline 4 & Tiếng Việt trung cấp: nghe & Bùi Thị Phương Chi & GT & $\begin{array}{l}\text { Tiếng Việt cho người nước ngoài } 3 \text { / Nguyễn Văn } \\
\text { Huệ chủ biên. - Tp. Hồ Chí Minh : Giáo dục, } 2003 .\end{array}$ & & & $\mathrm{C}$ & Khoa có \\
\hline 5 & Tiếng Việt trung cấp: nghe & Bùi Thị Phương Chi & $\mathrm{TKC}$ & www.vnexpress.net & & & C online & \\
\hline 6 & Tiếng Việt trung cấp: nghe & Bùi Thị Phương Chi & $\mathrm{TKC}$ & www.vtc.com.vn & & & C online & \\
\hline 7 & Tiếng Việt trung cấp: nghe & Bùi Thị Phương Chi & $\mathrm{TKC}$ & www.vov.org.vn & & & C online & \\
\hline 8 & Tiếng Việt trung cấp: nghe & Bùi Thị Phương Chi & $\mathrm{TKC}$ & www.tuoitre.com.vn & & & C online & \\
\hline 9 & Tiếng Việt trung cấp: nghe & Bùi Thị Phương Chi & $\mathrm{TKC}$ & $\begin{array}{l}\text { http://quehuongonline.vn/VietNam/Home/Hoc- } \\
\text { Tieng-Viet }\end{array}$ & & & C online & \\
\hline 10 & Tiếng Việt trung cấp: nghe & Bùi Thị Phương Chi & $\mathrm{TKC}$ & $\begin{array}{l}\text { Các bài hát được tải từ trên mạng nói về đất nước } \\
\text { quê hương Việt Nam }\end{array}$ & & & $\mathrm{C}$ & \\
\hline 11 & Tiếng Việt trung cấp: nghe & Bùi Thị Phương Chi & $\mathrm{TKC}$ & $\begin{array}{l}\text { Chùm phim: QUÀ TẶNG CUỘC SỐNG: } \\
\text { http://www.quatangcuocsong.vn/ }\end{array}$ & & & C online & \\
\hline 12 & Tiếng Việt trung cấp: nghe & Bùi Thị Phương Chi & TKC & Các đoạn phim ngắn thu từ chương trình truyền hình. & & & $\mathrm{C}$ & GV cung cấp \\
\hline 13 & Tiếng Việt trung cấp: nói & $\begin{array}{l}\text { Trần Thủy Vịnh } \\
\text { Phan Thái Bình }\end{array}$ & GT & Tài liệu soạn của giáo viên & & & $\mathrm{C}$ & GV cung cấp \\
\hline
\end{tabular}




\begin{tabular}{|c|c|c|c|c|c|c|c|c|}
\hline 14 & Tiếng Việt trung cấp: nói & $\begin{array}{l}\text { Trần Thủy Vịnh } \\
\text { Phan Thái Bình }\end{array}$ & GT & $\begin{array}{l}\text { Giáo trình tiếng Việt cho người nước ngoài } 2 \text { / } \\
\text { Nguyê̂n Văn Huệ (chủ biên). - Đại học Quốc Gia } \\
\text { TPHCM, 2008. }\end{array}$ & & & $\mathrm{C}$ & Khoa có \\
\hline 15 & Tiếng Việt trung cấp: nói & $\begin{array}{l}\text { Trần Thủy Vịnh } \\
\text { Phan Thái Bình }\end{array}$ & TKC & $\begin{array}{l}\text { Tiếng Việt : Dùng cho đại học đại cương / Nguyễn } \\
\text { Đức Dân. - H. : Giáo dục, 1998. - } 279 \text { tr. ; } 21 \text { cm. }\end{array}$ & $\begin{array}{l}\mathrm{V} 172.12 \\
\mathrm{~T} 306 \mathrm{~V}\end{array}$ & 1 & $\mathrm{R}$ & \\
\hline 16 & Tiếng Việt trung cấp: nói & $\begin{array}{l}\text { Trần Thủy Vịnh } \\
\text { Phan Thái Bình }\end{array}$ & TKC & $\begin{array}{l}\text { Tiếng Việt thực hành / Bùi Minh Toán, Lê A, Đỗ } \\
\text { Việt Hùng. - H. : Giáo dục, 1998. - } 275 \text { tr. ; } 21 \text { cm. }\end{array}$ & $\begin{array}{l}\mathrm{V} 172.12 \\
\mathrm{~T} 306 \mathrm{~V}\end{array}$ & 1 & $\mathrm{R}$ & \\
\hline 17 & Tiếng Việt trung cấp: nói & $\begin{array}{l}\text { Trần Thủy Vịnh } \\
\text { Phan Thái Bình }\end{array}$ & TKC & $\begin{array}{l}\text { Rèn luyện ngôn ngữ. T.1 / Phan Thiều. - H. : Giáo } \\
\text { dục, 1998. - } 283 \text { tr. ; } 21 \text { cm. }\end{array}$ & $\begin{array}{l}\text { V172.12 } \\
\text { R203L }\end{array}$ & 2,3 & $\mathrm{C}$ & \\
\hline 18 & Tiếng Việt trung cấp: nói & $\begin{array}{l}\text { Trần Thủy Vịnh } \\
\text { Phan Thái Bình }\end{array}$ & $\mathrm{TKC}$ & $\begin{array}{l}\text { Rèn luyện ngôn ngũ̃. T.2 / Phan Thiều. - H. : Giáo } \\
\text { dục, 1998. - } 21 \text { cm. }\end{array}$ & $\begin{array}{l}\text { V172.12 } \\
\text { R203L }\end{array}$ & $1,2,3,4$ & $\mathrm{C}$ & \\
\hline 19 & Tiếng Việt Trung cấp - Viết & $\begin{array}{l}\text { Nguyễn Thị Ngọc } \\
\text { Hân }\end{array}$ & GT & $\begin{array}{l}\text { Giáo trình luyện viết đúng từ và câu tiếng Việt : } \\
\text { dành cho sinh viên năm thứ nhất, khoa Việt Nam } \\
\text { học / Nguyễ̂n Thị Ngọc Hân. - Tp. Hồ Chí Minh : } \\
\text { Đại học Quốc gia Tp. Hồ Chí Minh, 2014. - } 207 \text { tr. } \\
21 \text { cm. }\end{array}$ & $\begin{array}{l}\text { V172.22 } \\
\text { GI-108T }\end{array}$ & $1,2,3,5$ & $\mathrm{C}$ & \\
\hline 20 & Tiếng Việt Trung cấp - Viết & Hân & TKC & $\begin{array}{l}\text { Giáo trình tiếng Việt cho người nước ngoài } 2 \text { / } \\
\text { Nguyê̂n Văn Huệ (chủ biên). - Đại học Quốc Gia } \\
\text { TPHCM, 2008. }\end{array}$ & & & $\mathrm{C}$ & Khoa có \\
\hline 21 & Tiếng Việt nâng cao đọc & Võ Thanh Hương & GT & $\begin{array}{l}\text { Giáo trình Tiếng Việt cho người nước ngoài, VSL } 4 \\
\text { / Nguyễn Văn Huệ. : Giáo dục, } 2004 .\end{array}$ & & & $\mathrm{C}$ & Khoa có \\
\hline 22 & Tiếng Việt nâng cao đọc & Võ Thanh Hương & TKC & $\begin{array}{l}\text { Bài đọc giáo viên tự soạn, cập nhật từ internet, bài } \\
\text { đọc soạn lại theo thông tin lầy nguồn từ các báo } \\
\text { trong nước. }\end{array}$ & & & $\mathrm{C}$ & GV cung cấp \\
\hline 23 & Tiếng Việt nâng cao đọc & Võ Thanh Hương & TKC & www.tuoitreonline.com.vn & & & C online & \\
\hline 24 & Tiếng Việt nâng cao - Nghe & Nguyễn Thị Hoàng Yến & GT & $\begin{array}{l}\text { Giáo trình nghe } 2 \text { - dành cho sinh viên chính qui } \\
\text { khoa VNH - lưu hành nội bộ. }\end{array}$ & & & $\mathrm{C}$ & Khoa có \\
\hline
\end{tabular}




\begin{tabular}{|c|c|c|c|c|c|c|c|c|}
\hline 25 & Tiếng Việt nâng cao - Nghe & Nguyễn Thị Hoàng Yến & GT & $\begin{array}{l}\text { Giáo trình Tiếng Việt cho người nước ngoài tập } 4 \text { / } \\
\text { Nguyê̂ên Văn Huệ . :Giáo dục, } 2004 .\end{array}$ & 495.92207 & & $\mathrm{C}$ & Khoa có \\
\hline 26 & Tiếng Việt nâng cao - Nghe & Nguyễn Thị Hoàng Yến & TKC & $\begin{array}{l}\text { Luyện nghe radio - tivi / Nguyễn Thị Hoàng Yến - } \\
\text { Trần Thị Tâm. - TP. HCM. : Khoa Việt Nam học, } \\
\text { Đại học KHXH\&NV TP.HCM. }\end{array}$ & & & $\mathrm{C}$ & Khoa có \\
\hline 27 & Tiếng Việt nâng cao - Nghe & Nguyễn Thị Hoàng Yến & TKC & www.vtc.com.vn & & & C online & \\
\hline 28 & Tiếng Việt nâng cao - Nghe & Nguyễn Thị Hoàng Yến & TKC & www.vov.org.vn & & & Conline & \\
\hline 29 & Tiếng Việt nâng cao - Nghe & Nguyễn Thị Hoàng Yến & TKC & www.tuoitre.com.vn & & & C online & \\
\hline 30 & Tiếng Việt nâng cao: Nói & $\begin{array}{l}\text { Bùi Thị Duyên Hải } \\
\text { Phan Thái Bình }\end{array}$ & GT & Tài liệu soạn của giáo viên. & & & $\mathrm{C}$ & GV cung cấp \\
\hline 31 & Tiếng Việt nâng cao: Nói & $\begin{array}{l}\text { Bùi Thị Duyên Hải } \\
\text { Phan Thái Bình }\end{array}$ & GT & $\begin{array}{l}\text { Giáo trình Tiếng Việt cho người nước ngoài tập } 4 \text { / } \\
\text { Nguyễên Văn Huệ . : Giáo dục, } 2003 \text {. }\end{array}$ & 495.92207 & Khoa có & $\mathrm{C}$ & \\
\hline 32 & Tiếng Việt nâng cao: Nói & $\begin{array}{l}\text { Bùi Thị Duyên Hải } \\
\text { Phan Thái Bình }\end{array}$ & TKC & $\begin{array}{l}\text { Tiếng Việt : Dùng cho đại học đại cương / Nguyễn } \\
\text { Đức Dân. - H. : Giáo dục, 1998. - } 279 \text { tr. ; } 21 \text { cm. }\end{array}$ & $\begin{array}{l}\text { V172.12 } \\
\text { T306V }\end{array}$ & 1 & $\mathrm{R}$ & YC 1997 \\
\hline 33 & Tiếng Việt nâng cao: Nói & $\begin{array}{l}\text { Bùi Thị Duyên Hải } \\
\text { Phan Thái Bình }\end{array}$ & TKC & $\begin{array}{l}\text { Tiếng Việt thực hành / Bùi Minh Toán, Lê A, Đỗ } \\
\text { Việt Hùng. - H. : Giáo dục, 1998. - } 275 \text { tr. ; } 21 \text { cm. }\end{array}$ & $\begin{array}{l}\mathrm{V} 172.12 \\
\mathrm{~T} 306 \mathrm{~V}\end{array}$ & 1 & $\mathrm{R}$ & YC 1997 \\
\hline 34 & Tiếng Việt nâng cao: Nói & $\begin{array}{l}\text { Bùi Thị Duyên Hải } \\
\text { Phan Thái Bình }\end{array}$ & TKC & $\begin{array}{l}\text { Rèn luyện ngôn ngữ. T.1 / Phan Thiều. - H. : Giáo } \\
\text { dục, 1998. - } 283 \text { tr. ; } 21 \text { cm. }\end{array}$ & $\begin{array}{l}\text { V172.12 } \\
\text { R203L }\end{array}$ & 2,3 & $\mathrm{C}$ & \\
\hline 35 & Tiếng Việt nâng cao: Nói & $\begin{array}{l}\text { Bùi Thị Duyên Hải } \\
\text { Phan Thái Bình }\end{array}$ & $\mathrm{TKC}$ & $\begin{array}{l}\text { Rèn luyện ngôn ngữ. T.2 / Phan Thiều. - H. : Giáo } \\
\text { dục, 1998. - } 21 \mathrm{~cm} \text {. }\end{array}$ & $\begin{array}{l}\text { V172.12 } \\
\text { R203L }\end{array}$ & $1,2,3,4$ & $\mathrm{C}$ & \\
\hline 36 & Tiếng Việt nâng cao: Nói & $\begin{array}{l}\text { Bùi Thị Duyên Hải } \\
\text { Phan Thái Bình }\end{array}$ & TKC & $\begin{array}{l}\text { Tiếng Việt thực hành / Nguyễn Minh Thuyết, } \\
\text { Nguyê̂n Văn Hiệp. - H. : Đại học Quốc gia Hà Nội, } \\
\text { 1997. - } 275 \text { tr. ; } 20 \text { cm. }\end{array}$ & $\begin{array}{l}\mathrm{V} 172.12 \\
\mathrm{~T} 306 \mathrm{~V}\end{array}$ & $1,2,3$ & $\mathrm{R}$ & YC 1999 \\
\hline
\end{tabular}




\begin{tabular}{|c|c|c|c|c|c|c|c|c|}
\hline 37 & Tiếng Việt nâng cao: Nói & $\begin{array}{l}\text { Bùi Thị Duyên Hải } \\
\text { Phan Thái Bình }\end{array}$ & TKC & $\begin{array}{l}\text { Nghiên cứu về ngữ pháp tiếng Việt / Nguyễn Kim } \\
\text { Thản. - Hà Nội : Giáo dục, 1997. - } 637 \text { tr. ; } 21 \text { cm. }\end{array}$ & $\begin{array}{c}\text { V172.12 } \\
\text { NGH305C }\end{array}$ & 1 & $\mathrm{R}$ & \\
\hline 38 & Tiếng Việt nâng cao - Viết & Huỳnh Công Hiển & & Tài liệu chính thức do giáo viên soạn và cung cấp. & & & $\mathrm{C}$ & GV cung cấp \\
\hline 39 & Tiếng Việt nâng cao - Viết & Huỳnh Công Hiển & & $\begin{array}{l}\text { Tiếng Việt thực hành / Nguyễn Minh Thuyết, } \\
\text { Nguyễn Văn Hiệp. - H. : Đại học Quốc gia Hà Nội, } \\
\text { 1997. - } 275 \text { tr. ; } 20 \text { cm. }\end{array}$ & $\begin{array}{l}\text { V172.12 } \\
\text { T306V }\end{array}$ & $1,2,3$ & $\mathrm{R}$ & \\
\hline 40 & Tiếng Việt nâng cao - Viết & Huỳnh Công Hiển & & $\begin{array}{l}\text { Tiếng Việt thực hành / Hà Thúc Hoan biên soạn. - } \\
\text { Tp. Hồ Chí Minh : Trường Đại học Sư phạm, 1996. - } \\
199 \text { tr. ; } 20 \text { cm. }\end{array}$ & $\begin{array}{l}\mathrm{V} 172.12 \\
\mathrm{~T} 306 \mathrm{~V}\end{array}$ & 4 & $\mathrm{R}$ & $\begin{array}{l}\text { YC nxb tp Hồ } \\
\text { Chí Minh, } 1997\end{array}$ \\
\hline 41 & Tiếng Việt học thuật - Đọc & Huỳnh Công Hiển & & $\begin{array}{l}\text { Tài liệu chính thức do giáo viên soạn, tập hợp và } \\
\text { cung câp. }\end{array}$ & & & $\mathrm{C}$ & GV cung cấp \\
\hline 42 & Tiếng Việt học thuật - Đọc & Huỳnh Công Hiển & TKC & $\begin{array}{l}\text { Giáo trình Tiếng Việt cho người nước ngoài tập } 4 \text { / } \\
\text { Nguyễn Văn Huệ. : Giáo dục, } 2004 .\end{array}$ & 495.92207 & Khoa có & $\mathrm{C}$ & \\
\hline 43 & Tiếng Việt học thuật - Đọc & Huỳnh Công Hiển & TKC & $\begin{array}{l}\text { Giáo trình Tiếng Viê̂t cho người nước ngoài tập } 5 \text { : } \\
\text { tài liệu lưu hành nội bộ / Nguyễn Văn Huệ }\end{array}$ & 495.92207 & Khoa có & $\mathrm{C}$ & \\
\hline 44 & Tiếng Việt học thuật - Đọc & Huỳnh Công Hiển & TKC & www.tuoitreonline.com.vn & & & Conline & \\
\hline 45 & Tiếng Việt học thuật - Đọc & Huỳnh Công Hiển & TKC & $\begin{array}{l}\text { Cần có cái nhìn khác về an ninh lương thực: } \\
\text { http://www.youtube.com/watch?v=5NN62UpQV_8 }\end{array}$ & & & C file & \\
\hline 46 & Tiếng Việt học thuật - Đọc & Huỳnh Công Hiển & TKC & $\begin{array}{l}\text { VTV1- Lãng phí thực phẩm ảnh hưởng đến môi } \\
\text { trường: } \\
\text { http://www.youtube.com/watch?v=ymIGsXymgQc }\end{array}$ & & & C file & \\
\hline 47 & Tiếng Việt học thuật - Đọc & Huỳnh Công Hiển & TKC & $\begin{array}{l}\text { Bùng nổ dân số thế giới: } \\
\text { http://www.youtube.com/watch?v=OouR9RLrHow }\end{array}$ & & & C file & \\
\hline
\end{tabular}




\begin{tabular}{|c|c|c|c|c|c|c|c|c|}
\hline 48 & Tiếng Việt học thuật - Đọc & Huỳnh Công Hiển & TKC & $\begin{array}{l}\text { Cơ cấu dân số vàng: } \\
\text { http://www.youtube.com/watch?v=xxAWUqmN7zs }\end{array}$ & & & C file & \\
\hline 49 & Tiếng Việt học thuật - Nói & Trần Thị Tươi & GT & $\begin{array}{l}\text { Giáo trình Tiếng Việt cho người nước ngoài tập } 5 \text { : } \\
\text { tài liệu luuu hành nội bộ / Nguyễn Văn Huệ. } 2003\end{array}$ & & & $\mathrm{C}$ & Khoa có \\
\hline 50 & Tiếng Việt học thuật - Nói & Trần Thị Tươi & TKC & 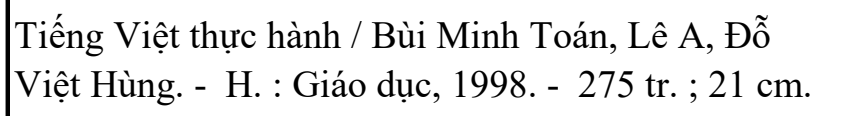 & $\begin{array}{l}\text { V172.12 } \\
\text { T306V }\end{array}$ & 1 & $\mathrm{R}$ & \\
\hline 51 & Tiếng Việt học thuật - Nói & Trần Thị Tươi & TKC & $\begin{array}{l}\text { Rèn luyện ngôn ngũ̃. T.1 / Phan Thiều. - H. : Giáo } \\
\text { dục, 1998. - } 283 \text { tr.; } 21 \text { cm. }\end{array}$ & $\begin{array}{l}\text { V172.12 } \\
\text { R203L }\end{array}$ & 2,3 & $\mathrm{C}$ & \\
\hline 52 & Tiếng Việt học thuật - Nói & Trần Thị Tươi & TKC & $\begin{array}{l}\text { Rèn luyện ngôn ngũ̃. T.2 / Phan Thiều. - H. : Giáo } \\
\text { dục, 1998. - } 21 \text { cm. }\end{array}$ & $\begin{array}{l}\text { V172.12 } \\
\text { R203L }\end{array}$ & $1,2,3,4$ & $\mathrm{C}$ & \\
\hline 53 & Tiếng Việt học thuật - Nói & Trần Thị Tươi & TKC & $\begin{array}{l}\text { Tiếng Việt thực hành / Nguyễn Minh Thuyết, } \\
\text { Nguyễ̂ Văn Hiệp. - H. : Đại học Quốc gia Hà Nội, } \\
\text { 1997. - } 275 \text { tr. ; } 20 \text { cm. }\end{array}$ & $\begin{array}{l}\mathrm{V} 172.12 \\
\mathrm{~T} 306 \mathrm{~V}\end{array}$ & $1,2,3$ & $\mathrm{R}$ & \\
\hline 54 & Tiếng Việt học thuật: viết & Nguyễn Vân Phổ & GT & $\begin{array}{l}\text { Luyện viết: viết tin : tài liệu lưu hành nội bộ / Lê Thị } \\
\text { Minh Hằng, Nguyê̂n Vân Phồ. - TP. HCM. : Trường } \\
\text { ĐHKHXH\&NV Tp.HCM, } 2007\end{array}$ & & & $\mathrm{C}$ & Khoa có \\
\hline 55 & Tiếng Việt học thuật: viết & Nguyễn Vân Phổ & GT & $\begin{array}{l}\text { Luyện viết: viết văn bản : tài liệu lưu hành nội bộ / } \\
\text { Lê Thị Minh Hằng, Nguyê̂n Vân Phố. - TP. HCM. : } \\
\text { Trường ĐHKHXH\&NV Tp.HCM, } 2007\end{array}$ & & & $\mathrm{C}$ & Khoa có \\
\hline 56 & Tiếng Việt học thuật: viết & Nguyễn Vân Phổ & TKC & $\begin{array}{l}\text { Hệ thống liên kết văn bản tiếng Việt / Trần Ngọc } \\
\text { Thêm. - H. : Khoa học xã hội, 1985. - 359tr., } 2 \text { tờ } \\
\text { đính ; 19cm }\end{array}$ & V171.5-2 & & $\mathrm{C}$ & TVKHTH \\
\hline 57 & Tiếng Việt học thuật: viết & Nguyễn Vân Phổ & TKC & $\begin{array}{l}\text { Phong cách học tiếng Việt / Đinh Trọng Lạc, } \\
\text { Nguyễn Thái Hòa. - H. : Giáo dục, 1997. - } 319 \text { tr. ; } \\
20 \text { cm. }\end{array}$ & $\begin{array}{l}\text { V172.12-7 } \\
\text { PH431C }\end{array}$ & 4 & $\mathrm{C}$ & \\
\hline
\end{tabular}




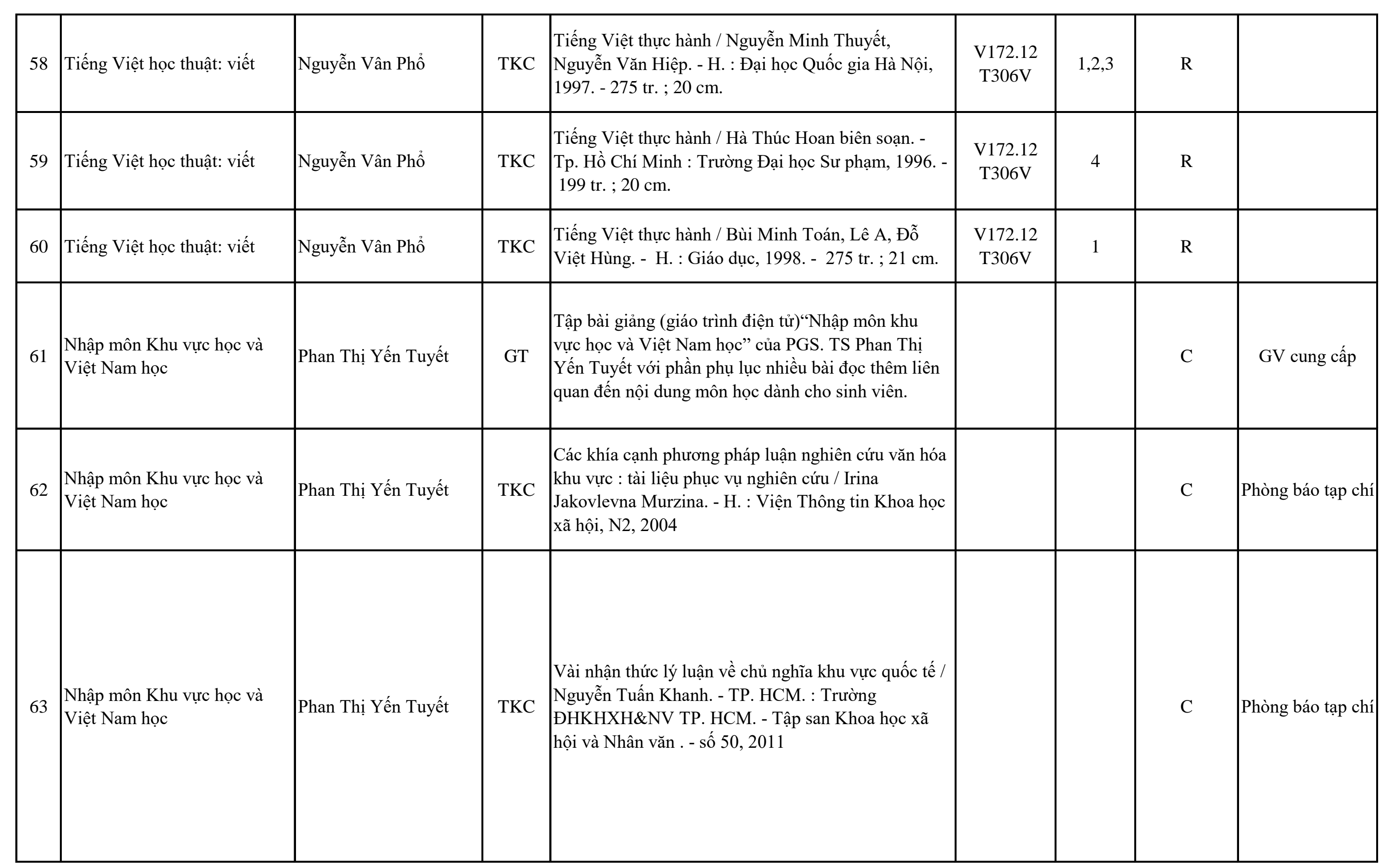


64

Nhập môn Khu vực học và

Việt Nam học
Phan Thị Yến Tuyết

Phan Thị Yến Tuyết

Nhập môn Khu vực học và

Việt Nam học

Nhập môn Khu vực học và

66 Viêt Nam hoc

Nhập môn Khu vực học và

Việt Nam học

68

Nhập môn Khu vực học và

Việt Nam họ

69 Tiếng Việt thương mại

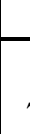

70 Tiếng Việt thương mại

guyễn Thị Hoàng Yến

71 Tiếng Việt thương mại

72

Văn hoá đảm bảo đời sống ở Việt Nam

Văn hoá đảm bảo đời sống ở Việt Nam
Về cách tiếp cận khu vực học / Phạm Đức Thành //

$\mathrm{TKC}$

Tạp chí nghiên cứu Đông Nam Á. - Năm 2001. - Số

1. - Tr. 19-23. số 1.
C

Khu vực học và nhập môn Việt Nam học / Trần Lê

Bảo. - H. : Giáo dục, 2008. - 159 tr. ; 24 cm.

Đ890(1)

KH500V www./gis.chinhphu.vn

www.suutap.com/bando/

CDs tham khảo: Các clip có nội dung liên quan đến môn học (10 clips)

Tài liệu/giáo trình chính: Giáo trình Tiếng Việt

GT

thương mại, Giáo viên phụ trách lớp biên soạn, in và phát.

Các bài báo, tạp chí về thương mại: Thời báo kinh tế, Báo thương mại online, ...

Các diễn đàn về Kinh tế thương mại của chương trình ti vi các đài VTV, HTV, SCTV 8,..

Tập bài giảng "Văn hóa bảo đảm đời sống" của

GT

PGS. TS. Phan Thi Yến Tuyết, 2014 (tài liệu lưu hành nội bộ).

Nhà ở - Trang phục - Ăn uống của các dân tộc vùng

TKC đồng bằng sông Cửu Long / Phan Thị Yến Tuyết. -

H. : Khoa học xã hội, 1993. - 376 tr. ; 21 cm.

\begin{tabular}{l|l|l} 
& & \\
\hline & & $\mathrm{C}$ online
\end{tabular}

c

$\mathrm{C}$

GV cung cấp

C

GV cung cấp

C

C

C

Khoa có 


\begin{tabular}{|c|c|c|c|c|c|c|c|c|}
\hline 74 & $\begin{array}{l}\text { Văn hoá đảm bảo đời sống ở } \\
\text { Việt Nam }\end{array}$ & Bùi Thị Duyên Hải & TKC & $\begin{array}{l}\text { Trang phục cổ truyền các dân tộc Việt Nam = } \\
\text { Traditional costume of Ethnic groups in Vietnam / } \\
\text { Ngô Đức Thịnh. - H. : Văn hóa dân tộc, 2000. - } 251 \\
\text { tr. ; } 27 \text { cm. }\end{array}$ & $\begin{array}{l}\mathrm{P} 52(1=\mathrm{A} / \mathrm{Z}) \\
-4 \mathrm{TR} 106 \mathrm{P}\end{array}$ & $0,1,2$ & $\mathrm{R}$ & \\
\hline 75 & $\begin{array}{l}\text { Văn hoá đảm bảo đời sống ở } \\
\text { Việt Nam }\end{array}$ & Bùi Thị Duyên Hải & TKC & $\begin{array}{l}\text { Góp phần nghien cứu văn hóa và tộc người / Nguyễn } \\
\text { Từ Chi ; Nguyễn Chí Bền, Trần Lâm Biền, Ngô Văn } \\
\text { Doanh sưu tập. - Hà Nội : Văn hóa Thông tin, 1996. - } \\
623 \text { tr.. }\end{array}$ & $\begin{array}{c}\mathrm{U} 111.15+\mathrm{P} \\
52\end{array}$ & & $\mathrm{R}$ & \\
\hline 76 & $\begin{array}{l}\text { Văn hoá đảm bảo đời sống ở } \\
\text { Việt Nam }\end{array}$ & Bùi Thị Duyên Hải & TKC & $\begin{array}{l}\text { Phim "Đi tìm trang phục Việt" / Nguyễn Hải Anh, } \\
\text { Trần Đức Tuấn, Trần Đức Long. - TP. HCM. : } \\
\text { Hãng phim Truyền hình Thành phố Hồ Chí Minh, } \\
2009\end{array}$ & 391.009597 & TVTT & $\mathrm{C}$ & \\
\hline 77 & $\begin{array}{l}\text { Văn hoá đảm bảo đời sống ở } \\
\text { Việt Nam }\end{array}$ & Bùi Thị Duyên Hải & TKC & http://www.vietnamtourism-info.com & & & C online & \\
\hline 78 & $\begin{array}{l}\text { Văn hoá đảm bảo đời sống ở } \\
\text { Việt Nam }\end{array}$ & Bùi Thị Duyên Hải & TKC & http://google.com & & & Conline & \\
\hline 79 & Kinh tế Việt Nam & Nguyễn Văn Thành & TKC & $\begin{array}{l}\text { Nông nghiệp Việt Nam từ cội nguồn đến đổi mới / } \\
\text { Bùi Huy Đáp, Nguyê̂n Điền. - H. : Chính trị Quốc } \\
\text { gia, 1996. - } 382 \text { tr. - } 19 \text { cm. }\end{array}$ & $\begin{array}{l}\text { Q9(1)32 } \\
\text { N455N }\end{array}$ & 1 & $\mathrm{R}$ & \\
\hline 80 & Kinh tế Việt Nam & Nguyễn Văn Thành & TKC & $\begin{array}{l}\text { Các văn kiện Đại hội đại biểu toàn quốc từ lần thứ } \\
\text { VI đến lần thứ XI / Đảng Cộng sản Việt Nam. - Sự } \\
\text { Thật, Chính trị Quốc gia, Hà Nội từ } 1976 \text { đến } 2011 .\end{array}$ & & & $\mathrm{C}$ & Khoa có \\
\hline 81 & Kinh tế Việt Nam & Nguyễn Văn Thành & TKC & $\begin{array}{l}45 \text { năm kinh tế Việt Nam (1945-1990) / Đào Văn } \\
\text { Tập chủ biên. - Hà Nội : Khoa học Xã hội, 1990. - } \\
423 \text { tr. }\end{array}$ & & & $\mathrm{R}$ & \\
\hline
\end{tabular}




\begin{tabular}{|c|c|c|c|c|c|c|c|c|}
\hline 82 & Kinh tế Việt Nam & Nguyễn Văn Thành & TKC & \begin{tabular}{|l} 
Tư duy kinh tế Việt Nam 1975-1989 (nhât ký thời \\
bao cấp) / Đặng Phong. - Tái bản lần thứ 3. - Hà Nội \\
: Tri thức, 2013. - 474 tr. : tranh ảnh ; 24 cm
\end{tabular} & $\mid 338.959722$ & & $\mathrm{C}$ & TVKHTH \\
\hline 83 & Kinh tế Việt Nam & Nguyễn Văn Thành & TKC & $\begin{array}{l}\text { Một số vấn đề về lịch sử kinh tế Việt Nam / Lê Quốc } \\
\text { Sứ - H. : Chính trị Quốc gia, 1998. - } 518 \text { tr. ; } 21 \text { cm. }\end{array}$ & $\begin{array}{l}\text { Q03(1) } \\
\text { M458S }\end{array}$ & $1,2,3$ & $\mathrm{C}$ & \\
\hline 84 & Kinh tế Việt Nam & Nguyễn Văn Thành & TKC & $\begin{array}{l}\text { Giáo trình lịch sử kinh tế / Nguyễn Trí Dĩnh, Phạm } \\
\text { Thị Quý chủ biên ... [và những người khác]. - Hà } \\
\text { Nội : Đại học Kinh tế Quốc dân, 2006. - } 431 \text { tr. }\end{array}$ & \begin{tabular}{|c|} 
Q03z7 GI- \\
$108 \mathrm{~T}$
\end{tabular} & $0,1,2,3,4$ & $\mathrm{R}$ & \\
\hline 85 & Kinh tế Việt Nam & Nguyễn Văn Thành & TKC & $\begin{array}{l}\text { Giáo trình kinh tế Việt Nam / Nguyễn Văn Thường, } \\
\text { Trần Khánh Hưng. - Hà Nội : Đại học Kinh tế Quốc } \\
\text { dân, 2010. - } 399 \text { tr. ; } 24 \text { cm.. }\end{array}$ & & & $\mathrm{C}$ & TVTT \\
\hline 86 & Kinh tế Việt Nam & Nguyễn Văn Thành & TKC & $\begin{array}{l}\text { Kinh tế Việt Nam thăng trầm và đột phá / Phạm } \\
\text { Minh Chính, Vương Quân Hoàng. - H. : Chính trị } \\
\text { Quốc gia, 2009. - } 554 \text { tr. ; } 22 \mathrm{~cm} .\end{array}$ & $\begin{array}{l}\text { Q9(1)0 } \\
\mathrm{K} 312 \mathrm{~T}\end{array}$ & $1,2,3,4$ & $\mathrm{C}$ & \\
\hline 87 & Kinh tế Việt Nam & Nguyễn Văn Thành & TKC & $\begin{array}{l}\text { Quá trình phát triển công nghiệp ở Việt Nam, triển } \\
\text { vơng công nghiệp hóa, hiện đại hóa đất nước / Phạm } \\
\text { Xuân Nam (Biên soạn). - H. : Khoa học Xã hội, } \\
\text { 1994. - } 318 \text { tr.; } 19 \text { m. }\end{array}$ & Q9(1)30-07 & $0,1,2$ & $\mathrm{C}$ & \\
\hline 88 & $\begin{array}{l}\text { Hệ thống chính trị Việt Nam } \\
\text { hiện đại }\end{array}$ & Nguyễn Văn Thành & GT & $\begin{array}{l}\text { Tập tài liệu hướng dẫn học tập môn "Hệ thống chính } \\
\text { trị Việt Nam hiện đại” do giáo viên phụ trách môn } \\
\text { học cung cấp. }\end{array}$ & & & $\mathrm{C}$ & GV cung cấp \\
\hline
\end{tabular}




\begin{tabular}{|c|c|c|c|c|c|c|c|c|}
\hline 89 & $\begin{array}{l}\text { Hệ thống chính trị Việt Nam } \\
\text { hiện đại }\end{array}$ & Nguyễn Văn Thành & TKC & $\begin{array}{l}\text { Phân công, phối hợp giữa các cơ quan trong thực } \\
\text { hiện các quyền lập pháp, hành pháp và tư pháp ở } \\
\text { Việt Nam : sách chuyên kháo - tham khảo / Cao Anh } \\
\text { Đô. - Hà Nội : Chính trị Quốc gia - Sự thật, 2013. - } \\
230 \text { tr. ; } 21 \mathrm{~cm} \text {. }\end{array}$ & R3(1)12 & 1 & $\mathrm{C}$ & \\
\hline 90 & $\begin{array}{l}\text { Hệ thống chính trị Việt Nam } \\
\text { hiện đại }\end{array}$ & Nguyễn Văn Thành & $\mathrm{TKC}$ & $\begin{array}{l}\text { Các văn kiện Đại hội đại biểu toàn quốc từ lần thứ } \\
\text { VI đến lần thứ XI / Đảng Cộng sản Việt Nam. - Sự } \\
\text { Thật, Chính trị Quốc gia, Hà Nội từ } 1976 \text { đê̂n } 2011 .\end{array}$ & & & $\mathrm{C}$ & Khoa có \\
\hline 91 & $\begin{array}{l}\text { Hệ thống chính trị Việt Nam } \\
\text { hiện đại }\end{array}$ & Nguyễn Văn Thành & TKC & $\begin{array}{l}\text { Hiến pháp nước Cộng hòa xã hội chủ nghĩa Việt } \\
\text { Nam. - Hà Nội : Lao động, 2013. - } 71 \text { tr.; } 19 \text { cm. }\end{array}$ & S69(1)11 & 1 & $\mathrm{C}$ & \\
\hline 92 & $\begin{array}{l}\text { Hệ thống chính trị Việt Nam } \\
\text { hiện đại }\end{array}$ & Nguyễn Văn Thành & $\mathrm{TKC}$ & $\begin{array}{l}\text { Hiến pháp Việt Nam (Năm 1946, 1959, } 1980 \text { và } \\
\text { 1992) . Vol. 1. - H. : Chính trị Quốc gia, 1995. - } \\
196 \text { tr. ; } 19 \text { cm. }\end{array}$ & $\begin{array}{l}\text { S620.1 } \\
\text { H305P }\end{array}$ & 1 & $\mathrm{R}$ & \\
\hline 93 & $\begin{array}{l}\text { Hệ thống chính trị Việt Nam } \\
\text { hiện đại }\end{array}$ & Nguyễn Văn Thành & TKC & $\begin{array}{l}\text { Nhà nước trong hệ thống chính trị ở Việt Nam hiện } \\
\text { nay / Lê Minh Quân ch.b. - H. : Chính trị Quốc gia, } \\
\text { 2009. - 165tr. ; 19cm }\end{array}$ & & $\mid \begin{array}{c}\mathrm{VN} \\
2929 / 200 \\
9, \mathrm{VN} \\
2930 / 200 \\
9\end{array}$ & $\mathrm{C}$ & TVKHTH \\
\hline
\end{tabular}




\begin{tabular}{|c|c|c|c|c|c|c|c|}
\hline 94 & $\begin{array}{l}\text { Hệ thống chính trị Việt Nam } \\
\text { hiện đại }\end{array}$ & Nguyễn Văn Thành & TKC & $\begin{array}{l}\text { Giáo trình lịch sử hành chính nhà nước Việt Nam / } \\
\text { Võ Văn Tuyê̂n, Phạm Thị Thu lan. - In lầ thứ } 1 . \text { - H } \\
\text { : Khoa học và kỹ thuật, 2008. - 427tr ; } 0 \text { cm }\end{array}$ & 351.09597 & $\mathrm{C}$ & TVĐHM \\
\hline 95 & $\begin{array}{l}\text { Hệ thống chính trị Việt Nam } \\
\text { hiện đại }\end{array}$ & Nguyễn Văn Thành & TKC & $\begin{array}{l}\text { Luật Mặt trận Tổ Quốc Việt Nam (sửa đổi) \& các } \\
\text { quy định pháp luật cần biết / Quang Minh hệ thống. - } \\
\text { Hà Nội : Lao động, 2015. - } 430 \text { tr. ; } 28 \text { cm }\end{array}$ & $\begin{array}{c}342.59704 \\
23\end{array}$ & $\mathrm{C}$ & TVKHTH \\
\hline 96 & $\begin{array}{l}\text { Hệ thống chính trị Việt Nam } \\
\text { hiện đại }\end{array}$ & Nguyễn Văn Thành & TKC & Luật tổ chức chính phủ năm 2001 & & C file & \\
\hline 97 & $\begin{array}{l}\text { Hệ thống chính trị Việt Nam } \\
\text { hiện đại }\end{array}$ & Nguyễn Văn Thành & TKC & $\begin{array}{l}\text { Luật Tổ chức Hội đồng nhân dân và Ủy ban nhân } \\
\text { dân năm } 2003 .\end{array}$ & & C file & \\
\hline 98 & $\begin{array}{l}\text { Hệ thống chính trị Việt Nam } \\
\text { hiện đại }\end{array}$ & Nguyễn Văn Thành & TKC & $\begin{array}{l}\text { Luật tổ chức chính quyền địa phương. - Hà Nội : } \\
\text { Chính trị Quốc gia - Sự thật, 2015. - } 155 \text { tr. ; } 19 \text { cm }\end{array}$ & $\begin{array}{c}342.59709 \\
23\end{array}$ & $\mathrm{C}$ & TVKHTH \\
\hline 99 & $\begin{array}{l}\text { Hệ thống chính trị Việt Nam } \\
\text { hiện đại }\end{array}$ & Nguyễn Văn Thành & TKC & Luật Tổ chức Tòa án Nhân dân năm 2002 & & C file & \\
\hline 100 & $\begin{array}{l}\begin{array}{l}\text { Hệ thống chính trị Việt Nam } \\
\text { hiện đại }\end{array} \\
\end{array}$ & Nguyễn Văn Thành & TKC & Luật Tổ chức Tòa án Nhân dân năm 2014. & & C file & \\
\hline 101 & $\begin{array}{l}\text { Hệ thống chính trị Việt Nam } \\
\text { hiện đại }\end{array}$ & Nguyễn Văn Thành & TKC & Luật Tổ chức Viện Kiểm sát Nhân dân năm 2002 & & C file & \\
\hline 102 & $\begin{array}{l}\text { Hệ thống chính trị Việt Nam } \\
\text { hiện đại }\end{array}$ & Nguyễn Văn Thành & TKC & Luật Tổ chức Viện Kiểm sát Nhân dân năm 2014. & & C file & \\
\hline 103 & $\begin{array}{l}\text { Hệ thống chính trị Việt Nam } \\
\text { hiện đại }\end{array}$ & Nguyễn Văn Thành & TKC & $\begin{array}{l}\text { Thực hiện thống nhất chức năng giai cấp và chức } \\
\text { năng xã hội của Nhà nước trong quá trình xây dựng } \\
\text { Nhà nước pháp quyền ở nước ta / Nguyễ̂ Đăng } \\
\text { Thông. - Hà Nội : Chính trị Quốc gia - Sự thật, } 2014 . \\
-234 \text { tr. ; } 21 \mathrm{~cm} \text {. }\end{array}$ & & $\mathrm{C}$ & TVTT \\
\hline 104 & $\begin{array}{l}\text { Hệ thống chính trị Việt Nam } \\
\text { hiện đại }\end{array}$ & Nguyễn Văn Thành & TKC & $\begin{array}{l}\text { Quá trình đổi mới hệ thống chính trị ở Việt Nam } \\
\text { (1986-2011) / Phạ Ngọc Trâm. -Hà Nội : Chính trị } \\
\text { Quốc gia - Sự thật, 2011. - } 407 \text { tr. ; } 21 \text { cm.. }\end{array}$ & & $\mathrm{C}$ & TVTT \\
\hline
\end{tabular}




\begin{tabular}{|c|c|c|c|c|c|c|c|c|}
\hline 105 & $\begin{array}{l}\text { Hệ thống chính trị Việt Nam } \\
\text { hiện đại }\end{array}$ & Nguyễn Văn Thành & $\mathrm{TKC}$ & Website Chính phủ Việt Nam: www.chinhphu.vn & & & C online & \\
\hline 106 & $\begin{array}{l}\text { Hệ thống chính trị Việt Nam } \\
\text { hiện đại }\end{array}$ & Nguyễn Văn Thành & $\mathrm{TKC}$ & $\begin{array}{l}\text { Website Đảng Cộng sản Việt Nam: } \\
\text { www.dangcongsan.vn }\end{array}$ & & & C online & \\
\hline 107 & Đại cương văn học Việt Nam & Trần Thị Mai Nhân & GT & Tập bài giảng do giảng viên biên soạn. & & & $\mathrm{C}$ & GV cung cấp \\
\hline 108 & Đại cương văn học Việt Nam & Trần Thị Mai Nhân & $\mathrm{TKC}$ & $\begin{array}{l}\text { Lịch sử văn học Việt Nam. Tập 1, Văn học dân gian } \\
\text { / Đinh Gia Khánh, Chu Xuân Diên. - Hà Nội : Đại } \\
\text { học và trung học chuyên nghiệp, 1977. - } 370 \text { tr. ; } 19 \\
\text { cm. }\end{array}$ & $\begin{array}{l}\text { V3(1)-3 } \\
\text { L302S }\end{array}$ & $0,1,2,3,4$ & $\mathrm{R}$ & \\
\hline 109 & Đại cương văn học Việt Nam & Trần Thị Mai Nhân & $\mathrm{TKC}$ & $\begin{array}{l}\text { Lịch sử văn học Việt Nam. Tập 2, Văn học dân gian } \\
\text { / Đinh Gia Khánh, Chu Xuân Diên. - Hà Nội : Đại } \\
\text { học và trung học chuyên nghiệp, 1977. - } 455 \text { tr.; } 19 \\
\text { cm. }\end{array}$ & $\begin{array}{l}\text { V3(1)-3 } \\
\text { L302S }\end{array}$ & $0,1,2,3,4$ & C & \\
\hline 110 & Đại cương văn học Việt Nam & Trần Thị Mai Nhân & $\mathrm{TKC}$ & $\begin{array}{l}\text { Văn học dân gian Việt Nam / Đinh Gia Khánh chủ } \\
\text { biên ; Chu Xuân Diên, Võ Quang Nhơn. - Tái bản } \\
\text { lần thứ mười hai. - H. : Giáo dục Việt Nam, 2009. - } \\
839 \text { tr. ; } 24 \mathrm{~cm} .\end{array}$ & V3(1)-6 & 1 & $\mathrm{R}$ & \\
\hline 111 & Đại cương văn học Việt Nam & Trần Thị Mai Nhân & $\mathrm{TKC}$ & $\begin{array}{l}\text { Đặc điểm lịch sử văn học Việt Nam / Lê Trí Viễn. - } \\
\text { Hà Nội : Đại học và Trung học Chuyên nghiệp, } \\
\text { 1987. - } 275 \text { tr. }\end{array}$ & $\begin{array}{l}\text { V5(1)-3 } \\
\text { Đ113Đ }\end{array}$ & 1 & $\mathrm{R}$ & \\
\hline 112 & Đại cương văn học Việt Nam & Trần Thị Mai Nhân & TKC & Website: hoinhavanvietnam.vn & & & C online & \\
\hline
\end{tabular}




\begin{tabular}{|c|c|c|c|c|c|c|c|}
\hline 113 & Đại cương văn học Việt Nam & Trần Thị Mai Nhân & TKC & Website: vietvan.vn & & & Conline \\
\hline 114 & Đại cương văn học Việt Nam & Trần Thị Mai Nhân & TKC & Website: khoavanhoc-ngonngu.edu.vn & & & Conline \\
\hline 115 & $\begin{array}{l}\text { Địa lý Việt Nam: Tự nhiên - } \\
\text { Nhân Văn - Kinh tế }\end{array}$ & Nguyễn Thu Cúc & GT & $\begin{array}{l}\text { Địa lý kinh tế Việt Nam / Văn Thái. - H. : Thống kê, } \\
\text { 2003. - } 259 \text { tr. }\end{array}$ & Q049(1) & 1,2 & $\mathrm{R}$ \\
\hline 116 & $\begin{array}{l}\text { Đia lý Việt Nam: Tự nhiên - } \\
\text { Nhân Văn - Kinh tế }\end{array}$ & Nguyễn Thu Cúc & GT & $\begin{array}{l}\text { Địa lý tự nhiên Việt Nam / Vũ Tự Lập. - TP.HCM. : } \\
\text { ĐH Sư phạm TP. HCM, } 2004\end{array}$ & $Đ 82$ & 1 & $\mathrm{C}$ \\
\hline 117 & $\begin{array}{l}\text { Điaa lý Việt Nam: Tự nhiên - } \\
\text { Nhân Văn - Kinh tế }\end{array}$ & Nguyễn Thu Cúc & TKC & Tổng cục thống kê, Niên gián thống kê & & & C online \\
\hline 118 & Ngữ pháp tiếng Việt & Nguyễn Vân Phổ & GT & $\begin{array}{l}\text { Ngữ pháp chức năng tiếng Việt. Q.1, Câu trong } \\
\text { tiếng Việt-Câu trúc-Nghĩa / Cao Xuân Hạo, Hoàng } \\
\text { Xuân Tâm, Nguyê̂n Văn Bằng... - H. : Giáo dục, } \\
2000 .\end{array}$ & V172.12-2 & 5.6 & $\mathrm{C}$ \\
\hline 119 & Ngữ pháp tiếng Việt & Nguyễn Vân Phổ & GT & $\begin{array}{l}\text { Ngữ pháp chức năng tiếng Việt. Q. 2, Ngữ đoạn và } \\
\text { từ loại / Cao Xuân Hạo chủ biên ; Nguyễn Văn } \\
\text { Bằng, Hoàng Xuân Tâm, Bùi Tất Tươm biên soạn. - } \\
\text { Hà Nội : Giáo Dục, 2005. - } 136 \text { tr.; } 20 \mathrm{~cm} \text {. }\end{array}$ & V172.12-2 & $0,1,2,3,4$ & $\mathrm{C}$ \\
\hline 120 & Ngữ pháp tiếng Việt & Nguyễn Vân Phổ & TKC & $\begin{array}{l}\text { Từ loại danh từ trong tiếng Việt hiện đại / Nguyễn } \\
\text { Tài Cẩn. - H. : Khoa học xã hội, 1975. - } 293 \text { tr.; } \\
19 \mathrm{~cm} \text {. }\end{array}$ & V171.5-3 & 2 & $\mathrm{R}$ \\
\hline
\end{tabular}




\begin{tabular}{|c|c|c|c|c|c|c|c|c|}
\hline 121 & Ngữ pháp tiếng Việt & Nguyễn Vân Phổ & TKC & $\begin{array}{l}\text { Ngữ pháp tiếng Việt : tiếng - từ ghép - đoản ngũ̃ / } \\
\text { Nguyê̂n Tài Cẩn. - H. : Đại học và trung học chuyên } \\
\text { nghiệp, 1981. - } 395 \text { tr. ; } 19 \mathrm{~cm} \text {. }\end{array}$ & $\begin{array}{l}\text { V172.12-2 } \\
\text { NG550P }\end{array}$ & 3 & $\mathrm{C}$ & \\
\hline 122 & Ngữ pháp tiếng Việt & Nguyễn Vân Phổ & TKC & $\begin{array}{l}\text { Ngữ pháp Tiếng Việt : từ loại / Đinh Văn Đức. - In } \\
\text { lại và có bồ sung. - Hà Nội : Đại học Quốc gia, } 2001 . \\
-321 \text { tr. ; } 19 \text { cm. }\end{array}$ & $\begin{array}{l}\text { V172.12-2 } \\
\text { NG500P }\end{array}$ & 1,2 & $\mathrm{R}$ & \\
\hline 123 & Ngữ pháp tiếng Việt & Nguyễn Vân Phổ & TKC & $\begin{array}{l}\text { Nghiên cứu về ngữ pháp tiếng Việt / Nguyễn Kim } \\
\text { Thăn. - H . : Giáo dục, 1997. - } 637 \text { tr. }\end{array}$ & V172.12-2 & 1 & $\mathrm{R}$ & \\
\hline 124 & Ngữ pháp tiếng Việt & Nguyễn Vân Phổ & TKC & $\begin{array}{l}\text { Từ loại tiếng Việt hiện đại / Lê Biên. - H. : Giáo dục, } \\
\text { 1999. - } 190 \text { tr. ; } 21 \mathrm{~cm} \text {. }\end{array}$ & & & $\mathrm{R}$ & \\
\hline 125 & Ngữ pháp tiếng Việt & Nguyễn Vân Phổ & TKC & $\begin{array}{l}\text { Động từ trong tiếng Việt / Nguyễn Kim Thản. - H. : } \\
\text { Khoa học Xã hội, 1999. - } 281 \text { tr. }\end{array}$ & V172.12-2 & $1,2,3,4$ & $\mathrm{C}$ & \\
\hline 126 & Ngữ pháp tiếng Việt & Nguyễn Vân Phổ & TKC & $\begin{array}{l}\text { Tiếng Việt mấy vấn đề ngữ âm - ngữ pháp - ngũ̃ } \\
\text { nghĩa / Cao Xuân Hạo. - H. : Giáo dục, 1998. - } 751 \\
\text { tr. ; } 24 \text { cm. }\end{array}$ & $\begin{array}{c}\text { V172.12-2 } \\
\text { T306V }\end{array}$ & $01,2,3,4$ & $\mathrm{R}$ & \\
\hline 127 & Ngữ pháp tiếng Việt & Nguyễn Vân Phổ & TKC & $\begin{array}{l}\text { Tiếng Việt sơ thảo ngũ̃ pháp chức năng / Cao Xuân } \\
\text { Hạo. - H. : Khoa học xã hội, 2006. - } 497 \text { tr.; } 24 \\
\text { cm. }\end{array}$ & V172.12-2 & $0,1,2,3,4$ & $\mathrm{C}$ & \\
\hline 128 & Ngữ pháp tiếng Việt & Nguyễn Vân Phổ & TKC & $\begin{array}{l}\text { Ngữ pháp tiếng Việt / Ủy ban khoa học xã hội. - H. : } \\
\text { Khoa học Xã hội, 1983. - } 283 \text { tr. }\end{array}$ & V172.12-2 & 3,4 & $\mathrm{R}$ & \\
\hline 129 & $\begin{array}{l}\text { ASEAN và quan hệ Việt Nam } \\
\text { - ASEAN }\end{array}$ & Nguyễn Thu Lan & GT & $\begin{array}{l}\text { Tập bài giảng: ASEAN và quan hệ Việt Nam - } \\
\text { ASEAN của PGS.TS. Phan Thị Yến Tuyết }\end{array}$ & & & $\mathrm{C}$ & GV cung cấp \\
\hline 130 & $\begin{array}{l}\text { ASEAN và quan hệ Việt Nam } \\
\text { - ASEAN }\end{array}$ & Nguyễn Thu Lan & TKC & $\begin{array}{l}\text { Các bài đọc thêm kèm theo ở phần phụ lục của tập } \\
\text { bài giảng }\end{array}$ & & & $\mathrm{C}$ & GV cung cấp \\
\hline
\end{tabular}




\begin{tabular}{|c|c|c|c|c|c|c|c|c|}
\hline 131 & $\begin{array}{l}\text { ASEAN và quan hệ Việt Nam } \\
\text { - ASEAN }\end{array}$ & Nguyễn Thu Lan & $\mathrm{TKC}$ & $\begin{array}{l}\text { Lịch sử bang giao Việt Nam - Đông Nam Á / Trần } \\
\text { Thị Mai. - Tp. Hồ Chí Minh : Đại học Quốc gia Tp. } \\
\text { Hồ Chí Minh, 2007. - } 250 \text { tr. ; } 21 \text { cm. }\end{array}$ & P3(1)-6 & $\begin{array}{c}0,1,2,3,4, \\
5,6\end{array} \mid$ & $\mathrm{R}$ & \\
\hline 132 & $\begin{array}{l}\text { ASEAN và quan hệ Việt Nam } \\
\text { - ASEAN }\end{array}$ & Nguyễn Thu Lan & $\mathrm{TKC}$ & $\begin{array}{l}\text { Lược sử Đông Nam Á / Phan Ngọc Liên, Nghiêm } \\
\text { Đình Vy, Đinh Ngọc Bảo, ... - H. : Giáo dục, } 2000\end{array}$ & P3(575)0 & 5 & R 1998 & YC 1999 \\
\hline 133 & $\begin{array}{l}\text { ASEAN và quan hệ Việt Nam } \\
\text { - ASEAN }\end{array}$ & Nguyễn Thu Lan & $\mathrm{TKC}$ & $\begin{array}{l}\text { Tổng quan về ASEAN và tiềm năng TP.HCM trong } \\
\text { tiến trình hội nhập / Nguyê̂n Quốc Lộc, Nguyê̂n } \\
\text { Công Khanh, Đoàn Thanh Hương. - Tồng hợp } \\
\text { TPHCM, 2004. - } 530 \text { tr. ; } 21 \text { cm.. }\end{array}$ & & & $\mathrm{C}$ & TVTT \\
\hline 134 & $\begin{array}{l}\text { ASEAN và quan hệ Việt Nam } \\
\text { - ASEAN }\end{array}$ & Nguyễn Thu Lan & $\mathrm{TKC}$ & $\begin{array}{l}\text { Lịch sử Đông Nam Á hiện đại : sách tham khảo / } \\
\text { Clive J. Christie ; Trần Văn Tụy ... [và những người } \\
\text { khác] dịch ; Lưu Đoàn Huynh hiệu đính.. - Hà Nội : } \\
\text { Chính trị Quốc gia, } 2000 . \text { - } 420 \text { tr. ; } 22 \text { cm.. }\end{array}$ & P3(575) & $0,1,3$ & $\mathrm{R}$ & \\
\hline 135 & $\begin{array}{l}\text { ASEAN và quan hệ Việt Nam } \\
\text { - ASEAN }\end{array}$ & Nguyễn Thu Lan & $\mathrm{TKC}$ & $\begin{array}{l}\text { Chính sách đối ngoại Việt Nam : tài liệu tham khảo } \\
\text { phục vụ giảng dạy. T.2, } 1975 \text { - } 2006 \text { / Nguyễn Vũ } \\
\text { Tùng biên soạn. - Hà Nội : Thế giới, 2007. - } 513 \text { tr. ; } \\
\text { 21cm.. }\end{array}$ & R4(1) & & $\mathrm{R}$ & \\
\hline 136 & $\begin{array}{l}\text { ASEAN và quan hệ Việt Nam } \\
\text { - ASEAN }\end{array}$ & Nguyễn Thu Lan & $\mathrm{TKC}$ & $\begin{array}{l}\text { http://ec.europa.eu/external_relations/asean/index_en } \\
\text { htmhttp://www.aseanfoundation.org/ }\end{array}$ & & & C online & \\
\hline 137 & $\begin{array}{l}\text { ASEAN và quan hệ Việt Nam } \\
\text { - ASEAN }\end{array}$ & Nguyễn Thu Lan & $\mathrm{TKC}$ & http://www.asean-tourism.com/ & & & Conline & \\
\hline 138 & $\begin{array}{l}\text { ASEAN và quan hệ Việt Nam } \\
\text { - ASEAN }\end{array}$ & Nguyễn Thu Lan & TKC & Google- hình ảnh & & & C online & \\
\hline 139 & $\begin{array}{l}\text { ASEAN và quan hệ Việt Nam } \\
\text { - ASEAN }\end{array}$ & Nguyễn Thu Lan & TKC & Bách khoa toàn thư mở Wikipedia & & & C online & \\
\hline 140 & $\begin{array}{l}\text { Các đặc trưng sinh thái môi } \\
\text { trường Việt Nam }\end{array}$ & Ngô Thanh Loan & & $\begin{array}{l}\text { Con người và môi trường / Hoàng Hưng. - } \\
\text { TP.HCM. : Trường Đại Học KHXH \& NV, 1998. - } \\
304 \text { tr. ; } 23 \text { cm. }\end{array}$ & B1z7 & $\begin{array}{c}1,2,3,4,5 \\
6\end{array}$ & $\mathrm{C}$ & \\
\hline
\end{tabular}




\begin{tabular}{|c|c|c|c|c|c|c|c|c|}
\hline 141 & $\begin{array}{l}\text { Các đặc trưng sinh thái môi } \\
\text { trường Việt Nam }\end{array}$ & Ngô Thanh Loan & & $\begin{array}{l}\text { Địa lý đồng bằng sông Cửu Long / Lê Bá Thảo. - } \\
\text { Đồng Tháp : Tồng hợp Đồng Tháp, 1986. - } 158 \text { tr. ; } \\
19 \text { cm. }\end{array}$ & $Đ 891(1-1 \mathrm{~N})$ & $1,2,3$ & $\mathrm{R}$ & \\
\hline 142 & $\begin{array}{l}\text { Các đặc trưng sinh thái môi } \\
\text { trường Việt Nam }\end{array}$ & Ngô Thanh Loan & & $\begin{array}{l}\text { Sinh thái môi trường đất / Lê Huy Bá. - Tp. Hồ Chí } \\
\text { Minh : Đại học Quốc gia Tp. Hồ Chí Minh, 2000. - } \\
240 \text { tr. ; } 21 \mathrm{~cm} \text {. }\end{array}$ & $\begin{array}{l}\text { B1:M03 } \\
\text { S317T }\end{array}$ & $1,2,3$ & $\mathrm{R}$ & \\
\hline 143 & \begin{tabular}{|l} 
Các đặa trưng sinh thái môi \\
trường Việt Nam
\end{tabular} & Ngô Thanh Loan & & $\begin{array}{l}\text { Hải dương học và biển Việt Nam / Nguyễn Văn } \\
\text { Phòng. - Tái bản lần thứ 1. - Hà Nội : Giáo dục, } \\
\text { 1998. - } 299 \text { tr. }\end{array}$ & Đ22 & & $\mathrm{R}$ & \\
\hline 144 & $\begin{array}{l}\text { Các đặc trưng sinh thái môi } \\
\text { trường Việt Nam }\end{array}$ & Ngô Thanh Loan & & $\begin{array}{l}\text { Rừng ngập nước ở Việt Nam : sách dùng cho giáo } \\
\text { viên / Phùng Trung Ngân, Châu Quang Hiền biên } \\
\text { soạn. - H. : Giáo dục, 1987. - } 135 \text { tr. ; } 20 \text { cm. }\end{array}$ & Z9:M39(2 & 2 & $\mathrm{R}$ & \\
\hline 145 & $\begin{array}{l}\text { Các đặc trưng sinh thái môi } \\
\text { trường Việt Nam }\end{array}$ & Ngô Thanh Loan & & $\begin{array}{l}\text { Địa lý tự nhiên Việt Nam : sách dùng trong các } \\
\text { trường Cao đẳng sư phạm. T.1: Phần khái quát / Vũ } \\
\text { Tự Lập. - H. : Giáo dục , 1978. - 193tr. : bản đồ ; } 27 \\
\text { cm }\end{array}$ & Đ890(2) & & $\mathrm{C}$ & TVKHTH \\
\hline 146 & $\begin{array}{l}\text { Các đặc trưng sinh thái môi } \\
\text { trường Việt Nam }\end{array}$ & Ngô Thanh Loan & & $\begin{array}{l}\text { Địa lý tự nhiên Việt Nam : sách dùng trong các } \\
\text { trường Cao đẳng sư phạm. T.2: Phần khu vực / Vũ } \\
\text { Tự Lập. - H. : Giáo dục, 1978. - 71tr. : minh họa ; } \\
27 \mathrm{~cm}\end{array}$ & Đ890(2) & & $\mathrm{C}$ & TVKHTH \\
\hline 147 & Các tôn giáo ở Việt Nam & Phan Thị Yến Tuyết & TKC & $\begin{array}{l}\text { Nhân học : một quan điểm về tình trạng nhân sinh / } \\
\text { Emily A. Schultz, Robert H. Lavenda; Phan Ngọc } \\
\text { Chiến, Hồ Liên Biện dịch ; Phan Văn Hy hiệu đính. - } \\
\text { H. : Chính trị Quốc gia, 2001. - } 506 \text { tr. }\end{array}$ & O55.04 & 0,1 & $\mathrm{R}$ & \\
\hline 148 & Các tôn giáo ở Việt Nam & Phan Thị Yến Tuyết & $\mathrm{TKC}$ & $\begin{array}{l}\text { Hồ Chí Minh về vấn đề tôn giáo, tín nguỡng : sách } \\
\text { tham khảo. - H. : KHoa học xã hội, 1996. - } 390 \text { tr.; } \\
19 \text { cm }\end{array}$ & A19 & 2.4 & $\mathrm{R}$ & \\
\hline
\end{tabular}




\begin{tabular}{|c|c|c|c|c|c|c|c|}
\hline 149 & Các tôn giáo ở Việt Nam & Phan Thị Yến Tuyết & TKC & $\begin{array}{l}\text { Hội thảo khoa học } 300 \text { năm Phât giáo Gia Định - Sài } \\
\text { Gòn Thành phố Hồ Chí Minh. - Tp. Hồ Chí Minh : } \\
\text { Nxb. Tp. Hồ Chí Minh, 2002. - } 415 \text { tr. }\end{array}$ & $\begin{array}{c}\mathrm{X} 350.9(2- \\
2 \mathrm{HCM})+\mathrm{X} 2 \\
9(2-2 \mathrm{HCM})\end{array}$ & & $\mathrm{R}$ \\
\hline 150 & Các tôn giáo ở Việt Nam & Phan Thị Yến Tuyết & TKC & $\begin{array}{l}\text { Về tôn giáo tín ngưỡng Việt Nam hiện nay / Đặng } \\
\text { Nghiêm Vạn chủ biên. - H. : Khoa học Xã hội, } 1996 .\end{array}$ & X29(1) & $0,1,2$ & $\mathrm{R}$ \\
\hline 151 & Các tôn giáo ở Việt Nam & Phan Thị Yến Tuyết & TKC & $\begin{array}{l}\text { Lý luận về tôn giáo và tình hình tôn giáo ở Việt Nam } \\
\text { : sách tham khảo / Đặng Nghiêm Vạn. - 2nd èd. - H. } \\
\text { : Chính trị quốc gia, 2005. }\end{array}$ & & & $\mathrm{C}$ \\
\hline 152 & Các tôn giáo ở Việt Nam & Phan Thị Yến Tuyết & TKC & $\begin{array}{l}\text { Đạo tứ ân hiếu nghĩa của người Việt Nam bộ (1867 - } \\
\text { 1975) / Đinh Văn Hạnh. - Tp. Hồ Chí Minh : Tré, } \\
\text { 1999. - } 353 \text { tr. ; } 20 \text { cm. }\end{array}$ & X29(1) & & $\mathrm{R}$ \\
\hline 153 & Các tôn giáo ở Việt Nam & Phan Thị Yến Tuyết & TKC & $\begin{array}{l}\text { Sấm giảng giáo lý Phật giáo Hòa Hảo của Đức } \\
\text { Huỳnh Giáo chủ / Ban đại diện Phật giáo Hòa Hảo. - } \\
\text { Hà Nội : Tôn giáo, } 2000 \text { - } 232 \text { tr. ; } 19 \text { cm. }\end{array}$ & X35 S120G & 1 & $\mathrm{C}$ \\
\hline 154 & Các tôn giáo ở Việt Nam & Phan Thị Yến Tuyết & TKC & $\begin{array}{l}\text { Tôn giáo học nhập môn / Đỗ Minh Hợp, Nguyễn } \\
\text { Công Oánh, Bùi Thành Phương. - H. : Tôn giáo, } \\
\text { 2006. - } 517 \text { tr.; } 21 \text { cm. }\end{array}$ & $\mathrm{X} 210.01$ & $0,1,2,3,4$ & $\mathrm{C}$ \\
\hline 155 & Các tôn giáo ở Việt Nam & Phan Thị Yến Tuyết & TKC & $\begin{array}{l}\text { Về văn hóa và tín ngưỡng truyền thống người Việt / } \\
\text { Léopold Cadière ; Đỗ Trinh Huệ dịch. - H. : Văn hóa } \\
\text { Thông tin, 1997. - } 285 \text { tr. }\end{array}$ & P52(1)-5 & 1,3 & $\mathrm{R}$ \\
\hline 156 & Các tôn giáo ở Việt Nam & Phan Thị Yến Tuyết & TKC & $\begin{array}{l}\text { Sự biến đổi của tôn giáo tín nguỡng ở Việt Nam hiện } \\
\text { nay / Lê Hồng Lý, Nguyê̂́n Thị Phương Châm tô̂ } \\
\text { chức bản thảo. - H. : Thế giới, 2008. - } 355 \text { tr. }\end{array}$ & X29(1) & $0,1,2,3,4$ & $\mathrm{C}$ \\
\hline 157 & Các tôn giáo ở Việt Nam & Phan Thị Yến Tuyết & TKC & $\begin{array}{l}\text { Một số vấn đề lịch sử thiên chúa giáo ở Việt Nam / } \\
\text { Đỗ Quang Hưng. - H. : Đại học tổng hợp, 1991. - } \\
115 \text { tr. }\end{array}$ & X375.09(1)- & 1,2 & $\mathrm{R}$ \\
\hline
\end{tabular}




\begin{tabular}{|c|c|c|c|c|c|c|c|c|}
\hline 158 & Các tôn giáo ở Việt Nam & Phan Thị Yến Tuyết & TKC & $\begin{array}{l}\text { Tôn giáo và mấy vấn đề tôn giáo Nam Bộ / Đỗ } \\
\text { Quang Hưng chủ biên. - Hà Nội : Khoa học Xã hội, } \\
\text { 2001. - } 428 \text { tr. }\end{array}$ & & & $\mathrm{R}$ & \\
\hline 159 & Các tôn giáo ở Việt Nam & Phan Thị Yến Tuyết & TKC & $\begin{array}{l}\text { Làng Hòa Hảo xưa và nay / Phạm Bích Hợp. - Tp. } \\
\text { Hồ Chí Minh : Nxb. Tp. Hồ Chí Minh, 1999. - } 183 \text { tr. }\end{array}$ & & & $\mathrm{R}$ & \\
\hline 160 & Các tôn giáo ở Việt Nam & Phan Thị Yến Tuyết & TKC & $\begin{array}{l}\text { Đạo phật trong cộng đồng người Việt ở Nam bộ - } \\
\text { Việt Nam : từ thế kỷ XVII đên 1975 / Trần Hồng } \\
\text { Liên. - H. : Khoa học Xã hội, 1995. - } 263 \text { tr. }\end{array}$ & X29(1N)-3 & $0,2,4$ & $\mathrm{R}$ & \\
\hline 161 & Các tôn giáo ở Việt Nam & Phan Thị Yến Tuyết & TKC & $\begin{array}{l}\text { Tín ngưỡng dân gian Huế / Trần Đại Vinh. - Huế : } \\
\text { Thuận Hóa, 1995. - } 281 \text { tr. }\end{array}$ & $\begin{array}{c}\mathrm{P} 52(1-1 \mathrm{Hu})- \\
5+\mathrm{X} 29(1- \\
1 \mathrm{Hu})\end{array}$ & & $\mathrm{R}$ & \\
\hline 162 & Các tôn giáo ở Việt Nam & Phan Thị Yến Tuyết & TKC & $\begin{array}{l}\text { Lịch sử Đạo Cao đài, quyển } 1 \text { / Đại đạo Tam kỳ phổ } \\
\text { độ̂, Cơ quan phổ thông giáo lý Đại đạo. - H. - Tôn } \\
\text { giáo, } 2005\end{array}$ & 299.592 & & $\mathrm{C}$ & TVTT \\
\hline 163 & Các tôn giáo ở Việt Nam & Phan Thị Yến Tuyết & TKC & $\begin{array}{l}\text { Đạo mẫu và các hình thức Shaman trong các tộc } \\
\text { người ở Việt Nam và Châu Á / Ngô Đức Thịnh. - Hà } \\
\text { Nội : Khoa học Xã hội, 2004. - } 793 \text { tr. }\end{array}$ & $\mathrm{X} 3-4$ & & $\mathrm{R}$ & \\
\hline 164 & Các tôn giáo ở Việt Nam & Phan Thị Yến Tuyết & TKC & $\begin{array}{l}\text { Tín ngưỡng dân gian ở thành phố Hồ Chí Minh : } \\
\text { sách tham khảo / Võ Thanh Bằng chủ biên. - Tp. Hồ } \\
\text { Chí Minh : Đại học Quốc gia Tp. Hồ Chí Minh, } \\
2008 \text { - } 442 \text { tr. ; } 21 \text { cm. }\end{array}$ & $\begin{array}{l}\text { P52(1- } \\
2 \mathrm{HCM})\end{array}$ & 1 & $\mathrm{R}$ & \\
\hline 165 & Các tôn giáo ở Việt Nam & Phan Thị Yến Tuyết & TKC & $\begin{array}{l}\text { Sổ tay hành hương Đất phương Nam / Huỳnh Ngọc } \\
\text { Trảng chủ biên ; Lý Lược Tam ... [và những người } \\
\text { khác] - - Tp. Hồ Chí Minh : Nxb. Tp. Hồ Chí Minh, } \\
\text { 2002. - } 446 \text { tr. : ảnh, bản đồ ; } 21 \mathrm{~cm} \text {. }\end{array}$ & $\begin{array}{r}\mathrm{X} 3-5 \mathrm{z} 8 \\
\mathrm{~S} 450 \mathrm{~T}\end{array}$ & $0,1,2,3,4$ & $\mathrm{C}$ & \\
\hline 166 & Các tôn giáo ở Việt Nam & Phan Thị Yến Tuyết & TKC & $\begin{array}{l}\text { The anthropology of religion : an introduction / } \\
\text { Fiona Bowie. - Oxford : Blackwell, } 2000\end{array}$ & O555.66 & & $\mathrm{R}$ & \\
\hline
\end{tabular}




\begin{tabular}{|c|c|c|c|c|c|c|c|c|}
\hline 167 & Các tôn giáo ở Việt Nam & Phan Thị Yến Tuyết & TKC & Tạp chí Tôn giáo & P. Báo - TC & & $\mathrm{C}$ & \\
\hline 168 & Các tôn giáo ở Việt Nam & Phan Thị Yến Tuyết & TKC & Tạp chí Dân tộc học & P. Báo - TC & & $\mathrm{C}$ & \\
\hline 169 & $\begin{array}{l}\text { Địa lý và cư dân các nước } \\
\text { Đông Nam Á }\end{array}$ & Nguyễn Thu Cúc & TKC & $\begin{array}{l}\text { Địa lý Đông Nam Á : những vấn đề kinh tế - xã hội / } \\
\text { Phan Huy Xu, Mai Phú Thanh. - Tái bản lần thứ bảy. } \\
\text { - Hà Nôi. : Giáo Dục, 2005. - } 240 \text { tr. : bản đồ ; } 21 \\
\text { cm.. }\end{array}$ & Đ890(575) & $0,1,2,3,4$ & $\mathrm{R}$ & \\
\hline 170 & $\begin{array}{l}\text { Địa lý và cư dân các nước } \\
\text { Đông Nam Á }\end{array}$ & Nguyễn Thu Cúc & TKC & Tổng cục thống kê, Niên giám thống kê & & & $\mathrm{C}$ & \\
\hline 171 & $\begin{array}{l}\text { Địa lý và cư dân các nước } \\
\text { Đông Nam Á }\end{array}$ & Nguyễn Thu Cúc & TKC & Tạp chí Đông Nam Á & & $\begin{array}{c}\text { Phòng } \\
\text { báo - tạp } \\
\text { chí } \\
\end{array}$ & $\mathrm{C}$ & \\
\hline 172 & Văn hóa du lịch Việt Nam & Bùi Thị Phương Chi & GT & Tập bài giảng của giáo viên. & & & $\mathrm{C}$ & GV cung cấp \\
\hline 173 & Văn hóa du lịch Việt Nam & Bùi Thị Phương Chi & TKC & $\begin{array}{l}\text { Về nội hàm Văn hoá du lịch / Bùi Thanh Thủy. - } \\
\text { Tạp chí Du lịch. Số 12, } 2009\end{array}$ & & $\begin{array}{c}\text { Phòng } \\
\text { báo - tạp } \\
\text { chí }\end{array}$ & $\mathrm{C}$ & \\
\hline 174 & Văn hóa du lịch Việt Nam & Bùi Thị Phương Chi & TKC & $\begin{array}{l}\text { Những tác động kinh tế - xã hội của du lịch đối với } \\
\text { các dân tộc thiểu số ở Sa Pa / Lâm Mai Lan, Phạm } \\
\text { Mộng. - Tạp chí Dân tộc học. - Số 4, 2000. - Tr.34 - } \\
\text { 43. }\end{array}$ & & $\begin{array}{l}\text { Phòng } \\
\text { báo tạp } \\
\text { chí }\end{array}$ & $\mathrm{R}$ & \\
\hline 175 & Văn hóa du lịch Việt Nam & Bùi Thị Phương Chi & TKC & $\begin{array}{l}\text { Tổng quan du lịch : giáo trình dùng cho sinh viên } \\
\text { Đại học và Cao đằng ngành Du lịch / Trần Nhoãn. - } \\
\text { Hà Nội : Trường Đại học Văn hóa Hà Nội, 2005. - } \\
196 \text { tr. }\end{array}$ & U518.11 & & $\mathrm{R}$ & \\
\hline 176 & Văn hóa du lịch Việt Nam & Bùi Thị Phương Chi & TKC & $\begin{array}{l}\text { Giáo trình du lị̣ch văn hóa. Những vấn đề lý luận và } \\
\text { nghiệp vụ / Trần Thúy Anh chủ biên. - H. : Giáo } \\
\text { dục, } 2011\end{array}$ & & & $\mathrm{C}$ & TVĐHM \\
\hline 177 & Văn hóa du lịch Việt Nam & Bùi Thị Phương Chi & TKC & $\begin{array}{l}\text { Giáo trình văn hóa du lịch : dùng trong các trường } \\
\text { THCN / Lê Thị Vân chủ biên.. - H. : Hà Nội, } 2006\end{array}$ & U114(1) & $0,1,2,3,4$ & $\mathrm{C}$ & \\
\hline
\end{tabular}




\begin{tabular}{|c|c|c|c|c|c|c|c|c|}
\hline 178 & Văn hóa du lịch Việt Nam & Bùi Thị Phương Chi & TKC & $\begin{array}{l}\text { Marketing du lịch / Robert Lanquar, Robert Hollier ; } \\
\text { Đỗ Ngọc Hải dịch. - H. : Thế giới, 1992. - } 159 \text { tr. }\end{array}$ & $\begin{array}{c}\text { Q549+ } \\
\text { Q529.0- } \\
211.1\end{array}$ & \begin{tabular}{|c|} 
Kho \\
$1,2,3,4$ \\
năm 2002
\end{tabular} & $\mathrm{C}$ & \\
\hline 179 & Văn hóa du lịch Việt Nam & Bùi Thị Phương Chi & TKC & $\begin{array}{l}\text { Kinh tế du lịch / Robert Lanquar ; Phạm Ngọc Uyển } \\
\text { dịch. - H. : Thế giới, 2002. - } 148 \text { tr. }\end{array}$ & Q549 & $0,1,2,3,4$ & $\mathrm{C}$ & \\
\hline 180 & Văn hóa du lịch Việt Nam & Bùi Thị Phương Chi & TKC & $\begin{array}{l}\text { Trang Web/CDs tham khảo: Các website của các } \\
\text { công ty du lịch, tồ chức du lịch của nhà nước... Tư } \\
\text { liệu khác: Các brochure, VCD, quảng cáo quảng bá } \\
\text { du lịch của các quốc gia, các cơ quan họat động } \\
\text { trong lĩnh vực du lịch. }\end{array}$ & & & $\mathrm{C}$ & internet \\
\hline 181 & Văn hóa du lịch Việt Nam & Bùi Thị Phương Chi & TKC & $\begin{array}{l}\text { http://www.dulichvietnam.com.vn - Tin tức du lịch } \\
\text { Việt Nam }\end{array}$ & & & $\mathrm{C}$ & \\
\hline 182 & Văn hóa du lịch Việt Nam & Bùi Thị Phương Chi & TKC & $\begin{array}{l}\text { http://www.vietnamtourism.gov.vn/ - Tổng cục du } \\
\text { lịch Việt Nam }\end{array}$ & & & $\mathrm{C}$ & \\
\hline 183 & Văn hóa du lịch Việt Nam & Bùi Thị Phương Chi & TKC & http://dulichvn.org.vn/ - Tổng cục du lịch Việt Nam & & & $\mathrm{C}$ & \\
\hline 184 & Văn hóa du lịch Việt Nam & Bùi Thị Phương Chi & TKC & http://www.vita.vn/ - Hiệp hội du lịch Việt Nam & & & $\mathrm{C}$ & \\
\hline 185 & Văn hóa du lịch Việt Nam & Bùi Thị Phương Chi & TKC & http://www.tapchidulich.com.vn/ & & & $\mathrm{C}$ & \\
\hline 186 & $\begin{array}{l}\text { Văn hóa ứng xử của người } \\
\text { Việt }\end{array}$ & Phan Thái Bình & GT & $\begin{array}{l}\text { Tập tài liệu đọc thêm : Các bài đọc thêm kèm theo ở } \\
\text { phần phụ lục của tập bài giảng }\end{array}$ & & & $\mathrm{C}$ & GV cung cấp \\
\hline 187 & $\begin{array}{l}\text { Văn hóa ứng xử của người } \\
\text { Việt }\end{array}$ & Phan Thái Bình & TKC & $\begin{array}{l}\text { Việt Nam văn hóa sử cương / Đào Duy Anh. - } \\
\text { TP.HCM, } 1992\end{array}$ & U113(1) & \begin{tabular}{|c} 
Có bản \\
của nhà \\
khác \\
năm \\
1998, \\
2000
\end{tabular} & $\mathrm{R}(1998)$ & \\
\hline
\end{tabular}




\begin{tabular}{|c|c|c|c|c|c|c|c|c|}
\hline 188 & $\begin{array}{l}\text { Văn hóa ứng xử của người } \\
\text { Việt }\end{array}$ & Phan Thái Bình & TKC & $\begin{array}{l}\text { Tác phẩm được tặng giải thưởng Hồ Chí Minh : lịch } \\
\text { sử Việt Nam / Đào Duy Anh. - H. : Khoa học Xã } \\
\text { hội, 2003. - } 1575 \text { tr. : Hình ảnh ; } 24 \text { cm. }\end{array}$ & P3(1)0,01 & $0,1,2,3,4 \mid$ & $\mathrm{C}$ & \\
\hline 189 & $\begin{array}{l}\text { Văn hóa ứng xử của người } \\
\text { Việt }\end{array}$ & Phan Thái Bình & TKC & $\begin{array}{l}\text { Đào Duy Anh nghiên cứu văn hóa và ngữ văn. - Hà } \\
\text { Nội : Giáo dục, } 2005\end{array}$ & & & $\mathrm{C}$ & TVTT \\
\hline 190 & $\begin{array}{l}\text { Văn hóa ứng xử của người } \\
\text { Việt }\end{array}$ & Phan Thái Bình & TKC & $\begin{array}{l}\text { Tín nguỡng dân gian ở thành phố Hồ Chí Minh : } \\
\text { sách tham khảo / Võ Thanh Bằng chủ biên. - Tp. Hồ } \\
\text { Chí Minh : Đại học Quốc gia Tp. Hồ Chí Minh, } \\
2008 \text { - } 442 \text { tr. ; } 21 \text { cm. }\end{array}$ & $\begin{array}{l}\text { P52(1- } \\
2 \mathrm{HCM})\end{array}$ & 1 & $\mathrm{R}$ & \\
\hline 191 & $\begin{array}{l}\text { Văn hóa ứng xử của người } \\
\text { Việt }\end{array}$ & Phan Thái Bình & TKC & $\begin{array}{l}\text { Úng xử ngôn ngữ trong giao tiếp gia đình người Việt } \\
\text { / Nguyễn Văn Khang, Nguyê̂n Thị Thanh Bình, Mai } \\
\text { Xuân Huy. - H. : Văn hóa - Thông tin, 1996. - } 188 \text { tr. } \\
\text {; } 19 \text { cm. }\end{array}$ & V100 & $1,2,3,4$ & $\mathrm{C}$ & \\
\hline 192 & $\begin{array}{l}\text { Văn hóa ứng xử của người } \\
\text { Việt }\end{array}$ & Phan Thái Bình & TKC & $\begin{array}{l}\text { Hỏi đáp về văn hóa độc đáo các dân tộc Việt Nam / } \\
\text { Vũ Ngọc Khánh, Trần Thị Hà, Hoàng Lan Anh sưu } \\
\text { tầm. - H. : Văn hóa dân tộc và Tạp chí Văn hóa nghệ } \\
\text { thuật, } 2000\end{array}$ & $\mid \begin{array}{c}\mathrm{P} 52(1=\mathrm{A} / \mathrm{Z}) \\
-7\end{array}$ & \begin{tabular}{|c|} 
Có bản \\
năm \\
2006, \\
2008 \\
kho \\
$1,2,3,4$
\end{tabular} & $\mathrm{C}$ & \\
\hline 193 & $\begin{array}{l}\text { Văn hóa ứng xử của người } \\
\text { Việt }\end{array}$ & Phan Thái Bình & TKC & $\begin{array}{l}\text { Lãng du trong văn hóa Việt Nam / Hữu Ngọc. : } \\
\text { Thanh niên, } 2014\end{array}$ & U114(1) & 1 & $\mathrm{R}$ & \\
\hline 194 & $\begin{array}{l}\text { Văn hóa ứng xử của người } \\
\text { Việt }\end{array}$ & Phan Thái Bình & TKC & $\begin{array}{l}\text { Ký họa Việt Nam đầu thế kỷ } 20 \text { / Nguyễn Mạnh } \\
\text { Hùng. - Tp. Hồ Chí Minh : Tré, 1989. - } 180 \text { tr. ; } 20 \\
\text { cm. }\end{array}$ & P3(1),01 & 0 & C & \\
\hline 195 & $\begin{array}{l}\text { Văn hóa ứng xử của người } \\
\text { Việt }\end{array}$ & Phan Thái Bình & TKC & $\begin{array}{l}\text { Góp phần nghiên cứu văn hóa Việt Nam, Tâp I, II / } \\
\text { Nguyễn Văn Huyên ; Hà Văn Tân chủ biên ; Đố } \\
\text { Trợng Quang, Phạm Thủy Ba, Trần Đỉnh dịch ; Diệu } \\
\text { Bình hiệu đính. - H. : Khoa học Xã hội, } 1996\end{array}$ & U111.15 & $\begin{array}{l}\text { Có bản } \\
\text { năm } \\
1995 \text { ở } \\
\text { kho } 1\end{array}$ & $\mathrm{R}(1995)$ & \\
\hline
\end{tabular}




\begin{tabular}{|c|c|c|c|c|c|c|c|}
\hline 196 & $\begin{array}{l}\text { Văn hóa ứng xử của người } \\
\text { Việt }\end{array}$ & Phan Thái Bình & TKC & $\begin{array}{l}\text { Ngôn từ, giới \& nhóm xã hội : từ thực tiễn tiếng Việt } \\
\text { / Lương Văn Hy chủ biên ; Diệp Đinhh Hòa,... [và } \\
\text { những người khác] biên soạn. - H. : Khoa học Xã } \\
\text { hội, } 2000 \text { - } 320 \text { tr. ; } 21 \text { cm. }\end{array}$ & V172.12-3 & $\begin{array}{c}0,1,2,3,4 \\
6\end{array} \mid$ & $\mathrm{R}$ \\
\hline 197 & $\begin{array}{l}\text { Văn hóa ứng xử của người } \\
\text { Việt }\end{array}$ & Phan Thái Bình & TKC & $\begin{array}{l}\text { Sổ tay hành hương Đất phương Nam / Huỳnh Ngọc } \\
\text { Trảng chủ biên. - Tp. Hồ Chí Minh : Nxb. Tp. Hồ } \\
\text { Chí Minh, 2002. - } 446 \text { tr. : ảnh, bản đồ } ; 21 \mathrm{~cm} \text {. }\end{array}$ & X3-5z8 & $0,1,2,3,4$ & $\mathrm{C}$ \\
\hline 198 & $\begin{array}{l}\text { Văn hóa ứng xử của người } \\
\text { Việt }\end{array}$ & Phan Thái Bình & TKC & $\begin{array}{l}\text { Nếp sống tình cảm của người Việt Nam / Lê Văn } \\
\text { Siêu. - Cà Mau. : Nxb. Cà Mau, 1993. - } 248 \text { tr. ; } 21 \\
\text { cm. }\end{array}$ & P52(1)-5 & $1,2,3,4$ & $\mathrm{R}$ \\
\hline 199 & Văn hoá Đông Nam Á & Đặng Văn Thắng & GT & $\begin{array}{l}\text { Lịch sử văn minh thế giới / Vũ Dương Ninh chủ biên } \\
\text {; Đinh Ngọc Bảo, Nguyễ̂n Quốc Hùng, Nguyễn Gia } \\
\text { Phu. - H. : Giáo dục, } 2000 \text { - } 371 \text { tr. ; } 20 \text { cm. }\end{array}$ & P3(0)3-7 & $0,1,2,3,4$ & $\mathrm{R}$ \\
\hline 200 & Văn hoá Đông Nam Á & Đặng Văn Thắng & GT & $\begin{array}{l}\text { Cơ sở văn hóa Việt Nam / Trần Ngọc Thêm. - Tái } \\
\text { bản lần 2. - H. : Giáo dục, 1999. - } 334 \text { tr. ; } 21 \text { cm. }\end{array}$ & U113(1) & 3,4 & $\mathrm{R}$ \\
\hline 201 & Văn hoá Đông Nam Á & Đặng Văn Thắng & TKC & $\begin{array}{l}\text { Di sản thế giới. T.1, Châu Á / Bùi Đẹp. - Tp.Hồ Chí } \\
\text { Minh : Tré, 1999. - } 298 \text { tr. ; } 20 \text { cm. }\end{array}$ & U111(0 & $1,2,3$ & $\mathrm{R}$ \\
\hline 202 & Văn hoá Đông Nam Á & Đặng Văn Thắng & TKC & $\begin{array}{l}\text { Di sản thế giới : Văn hóa, tự nhiên, hỗn hợp. T.2, } \\
\text { Châu Á / Bùi Đẹp. - Tp.Hồ Chí Minh : Trể, 1999. - } \\
349 \text { tr. ; } 20 \text { cm. }\end{array}$ & U111(0 & & $\mathrm{R}$ \\
\hline 203 & Văn hoá Đông Nam Á & Đặng Văn Thắng & TKC & $\begin{array}{l}\text { Di sản thế giới : văn hóa - tự nhiên - hỗn hợp. T.10, } \\
\text { Châu Á bồ sung / Bùi Đẹp biên soạn. - Tp. Hồ Chí } \\
\text { Minh : Trể, 2004. - } 310 \text { tr. }\end{array}$ & U774(0) & & $\mathrm{R}$ \\
\hline 204 & Văn hoá Đông Nam Á & Đặng Văn Thắng & TKC & $\begin{array}{l}\text { Nghệ thuật Đông Nam á / Cao Xuân Phổ, Ngô Văn } \\
\text { Doanh chủ biên. - H. : Viện Đông Nam á, 1984. - } \\
267 \text { tr.; } 19 \text { cm. }\end{array}$ & $\left|\begin{array}{c}\mathrm{P} 3(575): \mathrm{W} 0 \\
3(57)\end{array}\right|$ & 1 & $\mathrm{R}$ \\
\hline
\end{tabular}




\begin{tabular}{|c|c|c|c|c|c|c|c|}
\hline 205 & Văn hoá Đông Nam Á & Đặng Văn Thắng & TKC & $\begin{array}{l}\text { Di sản thế giới ở Việt Nam / Lê Tuấn Anh chủ biên ; } \\
\text { Lê Nhiệm [và những người khác] biên tập. - H. : } \\
\text { Tống cục Du lịch Việt Nam.Trung tâm Công nghệ } \\
\text { Thông tin Du lịch, } 2005 .\end{array}$ & U518(1) & & R 2004 \\
\hline 206 & Văn hoá Đông Nam Á & Đặng Văn Thắng & TKC & $\begin{array}{l}\text { Về khảo cổ học tiền sử Đông Nam Á : những vấn đề } \\
\text { lịch sử - văn hóa Đông Nam Á / Hà Văn Tấn chủ } \\
\text { biên ; Trình Năng Chung, Ngô Thê Phong, Vũ Công } \\
\text { Quý biên soạn. - H. : Viện Đông Nam á, 1983. - } 131 \\
\text { tr. ; } 19 \text { cm }\end{array}$ & P4(575) & 1 & $\mathrm{R}$ \\
\hline 207 & Văn hoá Đông Nam Á & Đặng Văn Thắng & TKC & $\begin{array}{l}\text { Văn hóa Đông Son ở Việt Nam / Hà Văn Tấn. - H. : } \\
\text { Khoa học Xã hội, 1994. - } 524 \text { tr. : có hình ảnh minh } \\
\text { họa ; } 24 \text { cm. }\end{array}$ & P4(1)-42 & 1 & $\mathrm{R}$ \\
\hline 208 & Văn hoá Đông Nam Á & Đặng Văn Thắng & TKC & $\begin{array}{l}\text { Lịch sử các nước Asean / Khắc Thành, Sanh phúc.- } \\
\text { H. : Trẻ, 2001. - } 286 \text { tr. ; } 19 \text { cm. }\end{array}$ & P3(575)0 & $0,1,2,3$ & $\mathrm{C}$ \\
\hline 209 & Văn hoá Đông Nam Á & Đặng Văn Thắng & TKC & $\begin{array}{l}\text { Lịch sử mỹ thuật viễn đông / Sherman E. Lee ; Trần } \\
\text { Văn Huân biên dịch. - H. : Mỹ thuật, 2007. - } 685 \text { tr. } \\
; 27 \text { cm. }\end{array}$ & W03(5) & $0,1,2$ & $\mathrm{R}$ \\
\hline 210 & Văn hoá Đông Nam Á & Đặng Văn Thắng & TKC & $\begin{array}{l}\text { Nghệ thuật Phật giáo và Hindu giáo ở Đồng bằng } \\
\text { sông Cứu Long trước thế kỷ X / Lê Thị Liên. - H. : } \\
\text { Thế giới, 2006. - } 255 \text { tr. ; } 29 \text { cm. }\end{array}$ & $\mathrm{X} 35+\mathrm{X} 33$ & $1,2,3$ & $\mathrm{R}$ \\
\hline 211 & Văn hoá Đông Nam Á & Đặng Văn Thắng & TKC & $\begin{array}{l}\text { Vương quốc Champa / Lương Ninh. - H. : Đại học } \\
\text { quốc gia Hà Nội, 2006. - } 400 \text { tr.; } 21 \mathrm{~cm} \text {. }\end{array}$ & P3(1)3 & $1,2,3,4$ & $\mathrm{R}$ \\
\hline 212 & Văn hoá Đông Nam Á & Đặng Văn Thắng & TKC & $\begin{array}{l}\text { Lịch sử Đông Nam Á / Lương Ninh chủ biên ; Đỗ } \\
\text { Thanh Bình, Trần Thị Vinh. - H. : Giáo dục, } 2008\end{array}$ & P3(575 & $0,1,2,3,4$ & $\mathrm{R}$ \\
\hline 213 & Văn hoá Đông Nam Á & Đặng Văn Thắng & TKC & $\begin{array}{l}\text { Danh thắng và kiến trúc Đông Nam Á / Ngô Văn } \\
\text { Doanh, 1949-. - In lần thứ 1. - H : Văn hóa - Thông } \\
\text { tin, 1998. - } 505 \text { tr ; } 20.5 \mathrm{~cm}\end{array}$ & К0(57) & & $\mathrm{R}$ \\
\hline
\end{tabular}




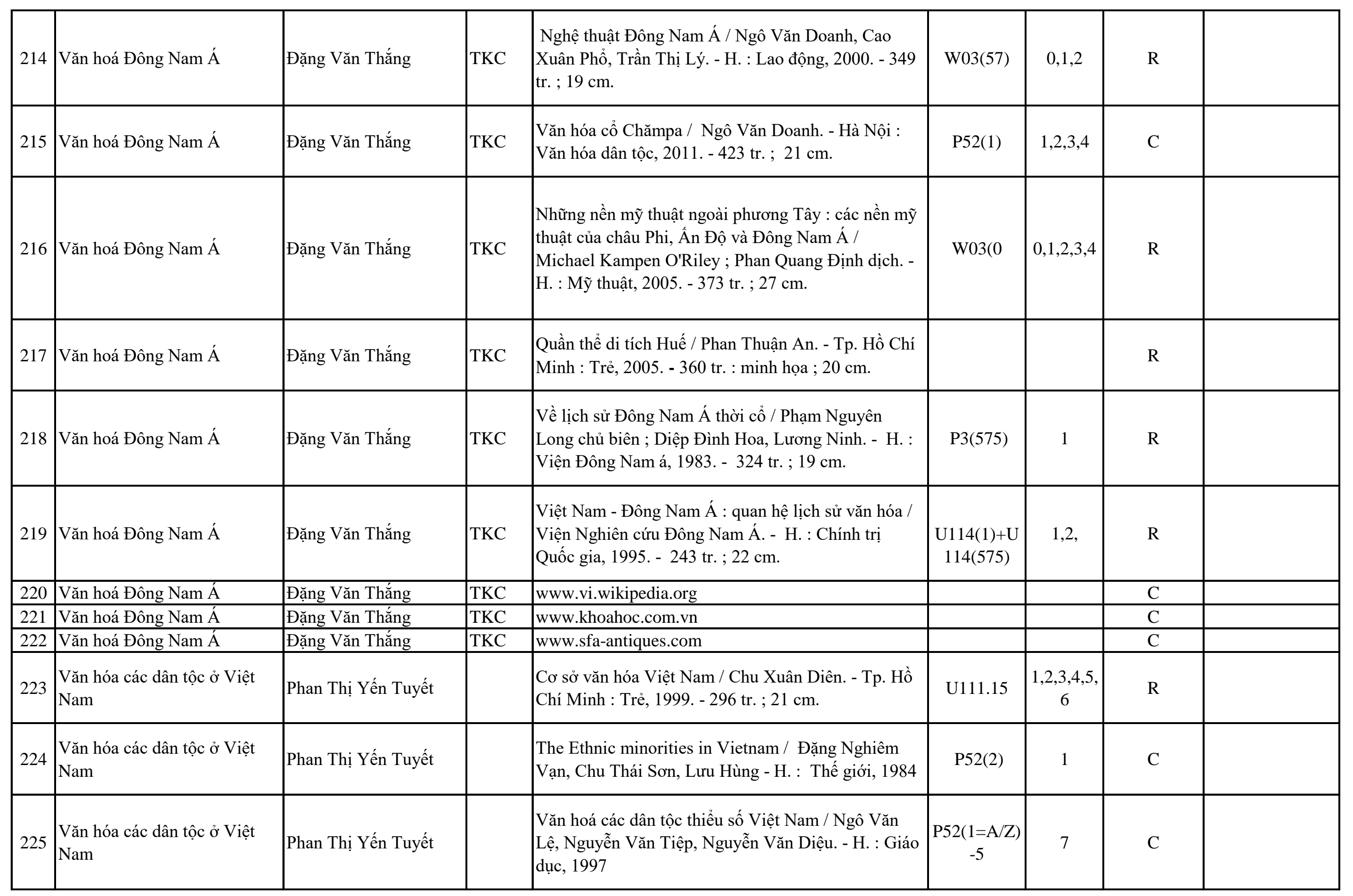




\begin{tabular}{|c|c|c|c|c|c|c|c|c|}
\hline 226 & $\begin{array}{l}\text { Văn hóa các dân tộc ở Việt } \\
\text { Nam }\end{array}$ & Phan Thị Yến Tuyết & & $\begin{array}{l}\text { Bảo tồn và phát huy bản sắc văn hóa dân tộc / } \\
\text { Trường ĐHKHXH\&NV và cơ quan hợp tác. - TP. } \\
\text { HCM : Nxb. Tp. Hồ Chí Minh, 1999. - } 652 \text { tr. }\end{array}$ & U111.15 & $0,1,2,3,4$ & $\mathrm{C}$ & \\
\hline 227 & Khảo cổ học Việt Nam & Đặng Văn Thắng & GT & $\begin{array}{l}\text { Khảo cổ học Việt Nam. Tập I. Thời đại đá Việt Nam } \\
\text { / Hà Văn Tấn (chủ biên). - H. : Khoa học Xã hội, } \\
1998\end{array}$ & P4(1) & & $\mathrm{R}$ & \\
\hline 228 & Khảo cổ học Việt Nam & Đặng Văn Thắng & GT & $\begin{array}{l}\text { Một thế kỷ khảo cổ học Việt Nam. T.2 / Hà Văn } \\
\text { Tấn, ...[et al.]. - In lần thứ 1. - H : Khoa học xã hội, } \\
\text { 2005. - - 950tr ; } 27 \text { cm }\end{array}$ & & & $\mathrm{C}$ & TVĐHM \\
\hline 229 & Khảo cổ học Việt Nam & Đặng Văn Thắng & GT & $\begin{array}{l}\text { Những nền văn hóa khảo cổ tiêu biểu ở Việt Nam / } \\
\text { Phạm Văn Đấu, Phạm Võ Thanh Hà. - Hà Nội : Văn } \\
\text { hóa Thông tin, 2006. - } 334 \text { tr. }\end{array}$ & & & $\mathrm{R}$ & \\
\hline 230 & Khảo cổ học Việt Nam & Đặng Văn Thắng & TKC & $\begin{array}{l}\text { Di sản thế giới ở Việt Nam / Lê Tuấn Anh chủ biên ; } \\
\text { Lê Nhiệm [và những người khác] biên tập. - H. : } \\
\text { Tô̂ng cục Du lịch Việt Nam.Trung tâm Công nghệ } \\
\text { Thông tin Du lịch, 2008. - } 256 \text { tr. }\end{array}$ & U518(1) & & $\mathrm{R}$ & \\
\hline 231 & Khảo cổ học Việt Nam & Đặng Văn Thắng & TKC & $\begin{array}{l}\text { Khảo cổ học tiền sử và sơ sử thành phố Hồ Chí } \\
\text { Minh / Đặng Văn Thắng .... [và những người khác]. - } \\
\text { Tp. Hồ Chí Minh : Tré, 1998. - } 678 \text { tr. ; } 24 \text { cm }\end{array}$ & $\left|\begin{array}{c}\mathrm{P} 4(1- \\
2 \mathrm{HCM}) 2 / 3- \\
4\end{array}\right|$ & $0,1,2$ & $\mathrm{R}$ & \\
\hline 232 & Khảo cổ học Việt Nam & Đặng Văn Thắng & TKC & $\begin{array}{l}\text { Văn hóa Đông Son ở Việt Nam / Hà Văn Tấn. - H. : } \\
\text { Khoa học Xã hội, 1994. - } 524 \text { tr. : có hình ảnh minh } \\
\text { họa ; } 24 \text { cm. }\end{array}$ & P4(1)-42 & 1 & $\mathrm{R}$ & \\
\hline 233 & Khảo cổ học Việt Nam & Đặng Văn Thắng & TKC & $\begin{array}{l}\text { Theo dấu các văn hóa cổ / Hà Văn Tấn. - H. : Khoa } \\
\text { học Xã hội, } 1998 .\end{array}$ & P4(57) & $0,1,2,3$ & $\mathrm{R}$ & \\
\hline 234 & Khảo cổ học Việt Nam & Đặng Văn Thắng & TKC & $\begin{array}{l}\text { Đến với lịch sử - văn hóa Việt Nam / Hà Văn Tấn. - } \\
\text { H. : Hội nhà văn, 2005. - } 419 \text { tr. ; } 21 \text { cm. }\end{array}$ & P3(1)0 & $0,1,2,3,4$ & $\mathrm{R}$ & \\
\hline 235 & Khảo cổ học Việt Nam & Đặng Văn Thắng & TKC & $\begin{array}{l}\text { Các nền văn cổ ở Việt Nam / Hoàng Xuân Chinh. - } \\
\text { H. : Văn hóa Thông tin, } 2009 .\end{array}$ & U113(1) & $0,1,2,3,4$ & $\mathrm{C}$ & \\
\hline
\end{tabular}




\begin{tabular}{|c|c|c|c|c|c|c|c|c|}
\hline 236 & Khảo cổ học Việt Nam & Đặng Văn Thắng & TKC & $\begin{array}{l}\text { Dấu tích văn hóa thời Nguyễn / Hồ Vĩnh. - Huế : } \\
\text { Thuận Hóa, 2000. - } 144 \text { tr.; } 19 \text { cm. }\end{array}$ & $\begin{array}{c}\text { P3(1-4TT)- } \\
7\end{array}$ & 1 & $\mathrm{R}$ & \\
\hline 237 & Khảo cổ học Việt Nam & Đặng Văn Thắng & TKC & $\begin{array}{l}\text { Nguồn gốc về văn minh Chăm : các yếu tố bản địa, } \\
\text { các ảnh hưởng của Trung Quốc, Ân Độ ở miền } \\
\text { Trung Việt Nam qua kết quả khai quật Trà Kiệu } \\
\text { (Duy Xuyên, Quảng Nam - Đà Nẵng) } 1993 \text { / Ian } \\
\text { Glover, Mariko Yamagata. - Tạp chí Khảo cồ học. - } \\
\text { Số 3, 1995. - Tr.46- 61. }\end{array}$ & & \begin{tabular}{|c} 
Phòng \\
Báo - \\
Tạp chí \\
DTH
\end{tabular} & $\mathrm{R}$ & \\
\hline 238 & Khảo cổ học Việt Nam & Đặng Văn Thắng & TKC & $\begin{array}{l}\text { Di tích gốm cổ Bình Định - Mảnh gốm và sản phẩm } \\
\text { gốm liên quan / Kerry Nguyễn Long. - Tạp chí Khảo } \\
\text { cố học. - Số 3, 1998. - Tr.101- 111. }\end{array}$ & & & $\mathrm{R}$ & 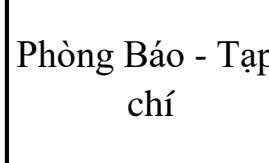 \\
\hline 239 & Khảo cổ học Việt Nam & Đặng Văn Thắng & TKC & $\begin{array}{l}\text { Tìm hiểu lịch sử kiến trúc tháp Champa / Lê Đình } \\
\text { Phụng. - H. : Viện Văn hóa, 2005. - } 317 \text { tr. ; } 24 \text { cm. }\end{array}$ & K0(1)-4 & $0,1,2,3,4$ & $\mathrm{R}$ & \\
\hline 240 & Khảo cổ học Việt Nam & Đặng Văn Thắng & TKC & $\begin{array}{l}\text { Nghệ thuật Phật giáo và Hindu giáo ở Đồng bằng } \\
\text { sông Cứu Long trước thế kỷ X / Lê Thị Liên. - H. : } \\
\text { Thế giới, } 2006 \text { - } 255 \text { tr. ; } 29 \text { cm. }\end{array}$ & $\mathrm{X} 35+\mathrm{X} 33$ & $1,2,3$ & $\mathrm{R}$ & \\
\hline 241 & Khảo cổ học Việt Nam & Đặng Văn Thắng & TKC & $\begin{array}{l}\text { Khảo cổ Đồng Nai : thời tiền sử / Lê Xuân Diệm, } \\
\text { Phạm Quang Sơn, Bùi Chí Hoàng. - Đồng Nai : Nxb } \\
\text { Đồng Nai, 1991. - } 222 \text { tr. ; } 22 \text { cm. }\end{array}$ & $\begin{array}{c}\mathrm{P} 4(1- \\
4 Đ \mathrm{DN}) 2-41\end{array}$ & $0,1,3$ & $\mathrm{R}$ & \\
\hline 242 & Khảo cổ học Việt Nam & Đặng Văn Thắng & TKC & $\begin{array}{l}\text { Văn hóa Óc Eo những khám phá mới / Lê Xuân } \\
\text { Diệm, Đào Linh Côn, Võ Sĩ Khải. - H. : Khoa học } \\
\text { Xã hội, 1995. - } 472 \text { tr. ; } 24 \text { cm }\end{array}$ & P4(1)-42 & 0,2 & $\mathrm{R}$ & \\
\hline 243 & Khảo cổ học Việt Nam & Đặng Văn Thắng & TKC & $\begin{array}{l}\text { Vương quốc Champa / Lương Ninh. - H. : Đại học } \\
\text { quốc gia Hà Nội, 2006. - } 400 \text { tr. ; } 21 \text { cm. }\end{array}$ & $\mathrm{P} 3(1) 3$ & $1,2,3,4$ & $\mathrm{R}$ & \\
\hline 244 & Khảo cổ học Việt Nam & Đặng Văn Thắng & TKC & $\begin{array}{l}\text { Nước Phù Nam / Lương Ninh. - Tp. Hồ Chí Minh : } \\
\text { Đại học quốc gia, 2006. - } 256 \text { tr. ; } 21 \mathrm{~cm} \text {. }\end{array}$ & P51(1 & $\begin{array}{c}0,1,2,3,4 \\
5,6\end{array} \mid$ & $\mathrm{R}$ & \\
\hline
\end{tabular}




\begin{tabular}{|c|c|c|c|c|c|c|c|}
\hline 245 & Khảo cổ học Việt Nam & Đặng Văn Thắng & TKC & $\begin{array}{l}\text { Văn hóa cổ Chămpa / Ngô Văn Doanh. - Hà Nội } \\
\text { Văn hóa dân tộc, 2011. - } 423 \text { tr. ; } 21 \text { cm. }\end{array}$ & P52(1) & $1,2,3,4$ & $\mathrm{C}$ \\
\hline 246 & Khảo cổ học Việt Nam & Đặng Văn Thắng & TKC & $\begin{array}{l}\text { Thánh địa Mỹ sơn / Ngô Văn Doanh. - Tp. Hồ Chí } \\
\text { Minh : Trẻ, 2003. - } 229 \text { tr. ; } 20 \text { cm. }\end{array}$ & $\begin{array}{c}\mathrm{P} 3(1-4 \mathrm{QN})- \\
9\end{array}$ & $0,1,2,3,4$ & $\mathrm{R}$ \\
\hline 247 & Khảo cổ học Việt Nam & Đặng Văn Thắng & TKC & $\begin{array}{l}\text { Văn hóa và cư dân đồng bằng sông Cửu Long / } \\
\text { Nguyễ̂ Công Bình, Lê Xuân Diệm, Mạc Đường. - } \\
\text { H. : Khoa học xã hội, 1990. - } 435 \text { tr. }\end{array}$ & U111(2) & & $\mathrm{R}$ \\
\hline 248 & Khảo cổ học Việt Nam & Đặng Văn Thắng & TKC & $\begin{array}{l}\text { Mỹ thuật thời Lý / Nguyễn Đức Nùng chủ biên ; } \\
\text { Nguyễn Du Chi... [và những người khác]. - H. : Văn } \\
\text { hóa, 1973. - } 87 \text { tr. ; } 26 \text { cm. }\end{array}$ & $\begin{array}{c}\mathrm{W} 03(1)+\mathrm{W} \\
14(2)\end{array}$ & 3 & $\mathrm{R}$ \\
\hline 249 & Khảo cổ học Việt Nam & Đặng Văn Thắng & TKC & $\begin{array}{l}\text { Mỹ thuật thời Trần / Nguyễn Đức Nùng chủ biên. - } \\
\text { H. : Văn Hóa, 1977. - } 137 \text { tr. ; } 26 \text { cm. }\end{array}$ & $\begin{array}{c}\mathrm{W} 13(1)+\mathrm{W} \\
14(1)\end{array}$ & 3,4 & $\mathrm{R}$ \\
\hline 250 & Khảo cổ học Việt Nam & Đặng Văn Thắng & TKC & $\begin{array}{l}\text { Mỹ thuật thời Lê - So / Nguyễn Đức Nùng chủ biên } \\
\text {... [và những người khác] tham gia. - Hà Nội : Văn } \\
\text { Hóa, 1978. - } 71 \text { tr. ; } 21 \mathrm{~cm} \text {. }\end{array}$ & W10(1)4 & $0,3,4$ & $\mathrm{R}$ \\
\hline 251 & Khảo cổ học Việt Nam & Đặng Văn Thắng & TKC & $\begin{array}{l}\text { Du khảo văn hóa Chăm = Peregrinations into Chăm } \\
\text { culture = Pérégrinations culturelles au Chămpa / } \\
\text { Nguyễ̂n Văn Kự, Ngô Văn Doanh, Andrew Hardy. - } \\
\text { Hà Nội : Thế giới, 2005. - } 407 \text { tr. ; } 28 \text { cm. }\end{array}$ & $\begin{array}{c}\mathrm{U} 113(1=\mathrm{CH} \\
)\end{array}$ & $0,1,2,3,4$ & $\mathrm{R}$ \\
\hline 252 & Khảo cổ học Việt Nam & Đặng Văn Thắng & TKC & $\begin{array}{l}\text { Quần thể di tích Huế / Phan Thuận An. - Tp. Hồ Chí } \\
\text { Minh : Tré, 2005. - } 360 \text { tr. : minh họa ; } 20 \text { cm. }\end{array}$ & & & $\mathrm{R}$ \\
\hline 253 & Khảo cổ học Việt Nam & Đặng Văn Thắng & TKC & $\begin{array}{l}\text { Hoàng Thành Thăng Long = Thang Long imperial } \\
\text { citadel . - Hà Nội : Văn hóa - Thông tin, 2006. - } 215 \\
\text { tr. ; } 29 \text { cm. }\end{array}$ & $\mathrm{P} 4(1-2 \mathrm{H})$ & $0,1,3,4$ & $\mathrm{R}$ \\
\hline 254 & Khảo cổ học Việt Nam & Đặng Văn Thắng & TKC & $\begin{array}{l}\text { Đền tháp Chămpa - bí ẩn xây dựng / Trần Bá Việt } \\
\text { chủ biên. - H. : Xây dựng, 2007. - } 344 \text { tr. : hình ảnh, } \\
\text { bản đồ ; } 20 \mathrm{~cm} \text {. }\end{array}$ & K0 & $0,1,2,3,4$ & $\mathrm{R}$ \\
\hline
\end{tabular}




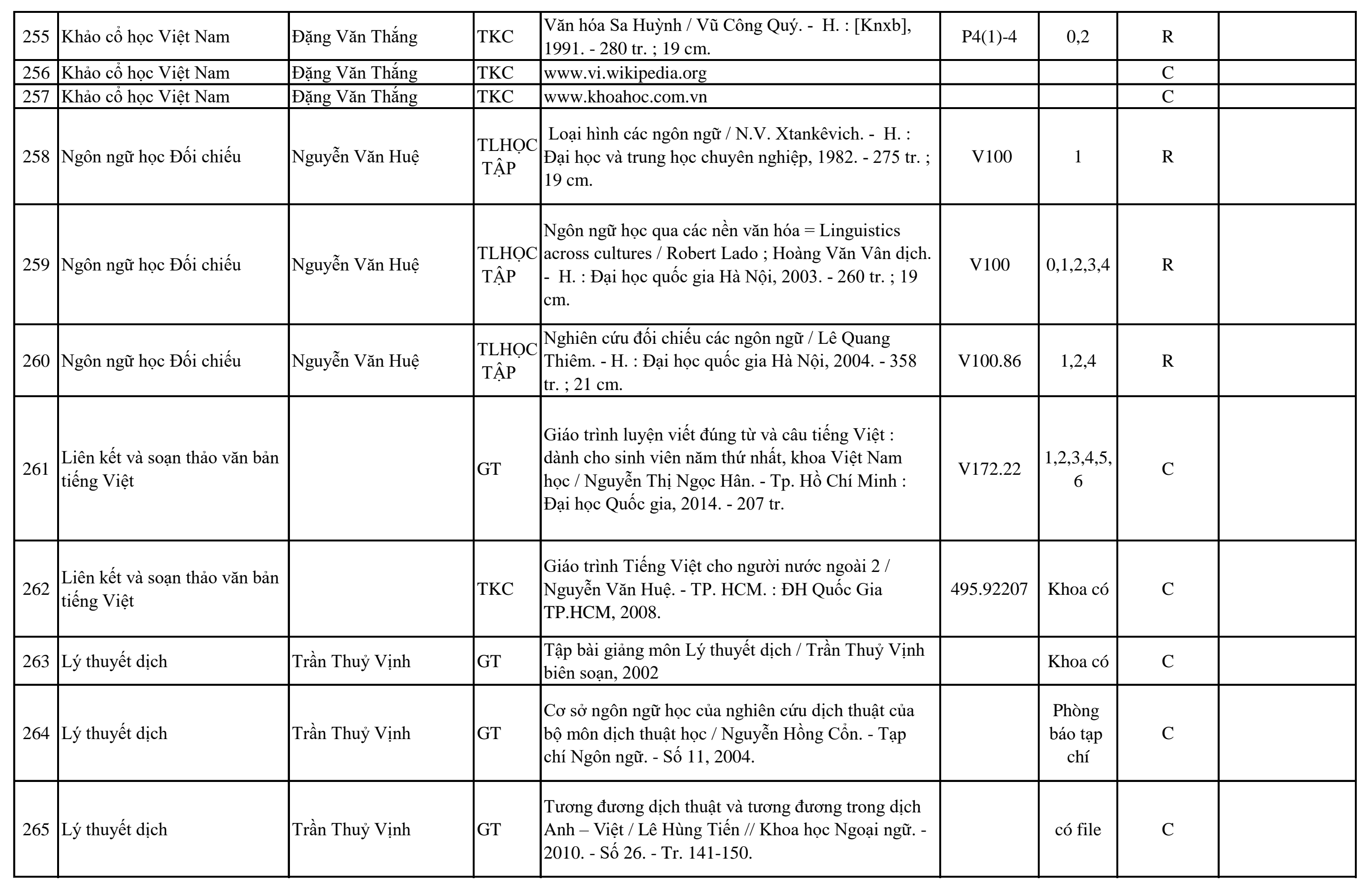




\begin{tabular}{|c|c|c|c|c|c|c|c|c|}
\hline 266 & Lý thuyết dịch & Trần Thuỷ Vịnh & TKC & $\begin{array}{l}\text { Dịch thuật : từ lý thuyết đến thực hành / Nguyễn } \\
\text { Thượng Hùng.- TP. HCM. - Văn hoá Sài Gòn, } 2006\end{array}$ & V107 & \begin{tabular}{|c|} 
Có bản \\
năm \\
2005 ở \\
kho \\
$0,1,2,3,4$
\end{tabular} & $\mathrm{C}$ & \\
\hline 267 & Lý thuyết dịch & Trần Thuỷ Vịnh & TKC & $\begin{array}{l}\text { Nhập môn nghiên cứu dịch thuật : lý thuyết và ứng } \\
\text { dụng / Jeremy Munday ; Trịnh Lữ dịch. - H. : Tri } \\
\text { thức, 2009. - } 303 \text { tr. ; } 24 \mathrm{~cm} \text {. }\end{array}$ & V107z7 & $0,1,2,3,4$ & $\mathrm{C}$ & \\
\hline 268 & Ngữ âm tiếng Việt thực hành & Phan Trần Công & GT & $\begin{array}{l}\text { Giáo trình chính: Tài liệu lưu hành nội bộ (giáo viên } \\
\text { soạn). }\end{array}$ & & & $\mathrm{C}$ & GV cung cấp \\
\hline 269 & Ngữ âm tiếng Việt thực hành & Phan Trần Công & GT & Một số bài báo và sách về ngữ âm tiếng Việt. & & & $\mathrm{C}$ & \\
\hline 270 & Ngữ âm tiếng Việt thực hành & Phan Trần Công & TKC & $\begin{array}{l}\text { Cơ cấu ngũ âm tiếng Việt / Đinh Lê Thur, Nguyễn } \\
\text { Văn Huệ. - H. : Giáo dục, 1998. - } 213 \text { tr. ; } 21 \text { cm. }\end{array}$ & V172.12 & $\begin{array}{c}1,2,3,4,5 \\
6\end{array} \mid$ & $\mathrm{R}$ & \\
\hline 271 & Ngữ âm tiếng Việt thực hành & Phan Trần Công & TKC & $\begin{array}{l}\text { Ngữ âm tiếng Việt / Đoàn Thiện Thuật. - H. : Đại } \\
\text { học Quốc gia Hà Nội, } 2003 .\end{array}$ & V172.12 & 1 & $\mathrm{R}$ & \\
\hline 272 & Ngữ âm tiếng Việt thực hành & Phan Trần Công & TKC & $\begin{array}{l}\text { Nhập môn ngôn ngữ học / Bùi Khánh Thế. - H. } \\
\text { Giáo dục, 1995. - } 208 \text { tr. ; } 20 \mathrm{~cm} \text {. }\end{array}$ & $\mathrm{V} 10$ & $1,2,3,4$ & $\mathrm{C}$ & \\
\hline 273 & Ngữ âm tiếng Việt thực hành & Phan Trần Công & TKC & $\begin{array}{l}\text { Tiếng việt trên các miền đất nước : phương ngũ̃ học } \\
\text { / Hoàng Thị Châu. - H. : Khoa học xã hội, 1989. - } \\
284 \text { tr. ; } 19 \text { cm. }\end{array}$ & V171.5-5 & $0,2,3$ & $\mathrm{R}$ & \\
\hline 274 & Phương ngữ tiếng Việt & Lê Khắc Cường & GT & $\begin{array}{l}\text { Phương ngữ học tiếng Việt / Hoàng Thị Châu. - Hà } \\
\text { Nội. : Đại học Quốc gia Hà Nội, } 2004 .\end{array}$ & V172.12-5 & $1,2,3,4$ & $\mathrm{C}$ & \\
\hline 275 & Phương ngữ tiếng Việt & Lê Khắc Cường & TKC & $\begin{array}{l}\text { Ngữ âm tiếng Việt / Đoàn Thiện Thuật. - H. : Đại } \\
\text { học và trung học chuyên nghiệp, 1977. - } 373 \text { tr.; } 19 \\
\text { cm. }\end{array}$ & V172.12-1 & $2,3,4$ & $\mathrm{R}$ & \\
\hline
\end{tabular}




\begin{tabular}{|c|c|c|c|c|c|c|c|c|}
\hline 276 & Phương ngữ tiếng Việt & Lê Khắc Cường & TKC & $\begin{array}{l}\text { Phương ngữ Nam bộ : những khác biêt về từ vựng - } \\
\text { ngữ nghĩa / Trần Thi Ngọc Lang. - H. : Khoa học Xã } \\
\text { hội, 1995. - } 208 \text { tr. ; } 21 \text { cm. }\end{array}$ & V171.5-2 & 1,2 & $\mathrm{R}$ & \\
\hline 277 & Phương ngữ tiếng Việt & Lê Khắc Cường & TKC & $\begin{array}{l}\text { Tiếng Việt mấy vấn đề ngữ âm - ngữ pháp - ngữ } \\
\text { nghĩa / Cao Xuân Hạo. - H. : Giáo dục, 1998. - } 751 \\
\text { tr. ; } 24 \text { cm. }\end{array}$ & V172.12-2 & $0,1,2,3,4$ & $\mathrm{R}$ & \\
\hline 278 & Tiếng Việt báo chí & Lê Khắc Cường & GT & Tiếng Việt báo chí (powerpoint) / Lê Khắc Cường. & & & $\mathrm{C}$ & GV cung cấp \\
\hline 279 & Tiếng Việt báo chí & Lê Khắc Cường & TKC & $\begin{array}{l}\text { Ngôn ngữ báo chí - Những vấn đề cơ bản / Nguyễn } \\
\text { Đức Dân. - H. : Giáo dục, 2007. - } 244 \text { tr. ; } 21 \text { cm. }\end{array}$ & U612.1 & $0,1,2,3,4$ & $\mathrm{C}$ & \\
\hline 280 & Tiếng Việt báo chí & Lê Khắc Cường & TKC & $\begin{array}{l}\text { Phong cách học thực hành tiếng Việt (dành cho sinh } \\
\text { viên nước ngoài) : bài giảng / Lê Thị Minh Hằng. - } \\
\text { TP. HCM. : Đại học Quốc gia, 2014. - } 176 \text { tr. ; } 21 \\
\text { cm. }\end{array}$ & V172.12-7 & $\begin{array}{c}0,1,2,3,4 \\
5,6\end{array}$ & $\mathrm{C}$ & \\
\hline 281 & Tiếng Việt báo chí & Lê Khắc Cường & TKC & $\begin{array}{l}\text { Các thể loại báo chí : sách tham khảo nghieêp vụ / } \\
\text { A.A. Chertưchơnưi ; Đào Tấn Anh, Trần Kiều Vân } \\
\text { dịch. - Hà Nội : Thông tấn, 2004. - } 553 \text { tr.; } 19 \text { cm. }\end{array}$ & U612.1 & $0,1,2,3,4$ & $\mathrm{R}$ & \\
\hline 282 & Tiếng Việt báo chí & Lê Khắc Cường & TKC & $\begin{array}{l}\text { Ngôn ngữ báo chí tiếng Việt : từ Gia Định Báo đến } \\
\text { báo trực tuyến / Lê Khắc Cường. - Tạp chí Người } \\
\text { làm báo - - Số 41, 42, } 2011\end{array}$ & & & $\mathrm{C}$ & $\begin{array}{c}\text { Phòng Báo - Tạp } \\
\text { chí }\end{array}$ \\
\hline 283 & Từ vựng Tiếng Việt thực hành & Nguyễn Thanh Thủy & GT & $\begin{array}{l}\text { Từ vựng học tiếng Việt / Nguyễn Thiện Giáp. - H. } \\
\text { Giáo dục, 1998. - } 339 \text { tr. ; } 21 \text { cm. }\end{array}$ & V172.12-3 & $\mid 1,2,3,4,5$ & $\mathrm{R}$ & \\
\hline 284 & Từ vựng Tiếng Việt thực hành & Nguyễn Thanh Thủy & & $\begin{array}{l}\begin{array}{l}\text { Bài giảng tóm tắt do giáo viên phụ trách môn học } \\
\text { soạn lại. }\end{array} \\
\end{array}$ & & & $\mathrm{C}$ & GV cung cấp \\
\hline 285 & Từ vựng Tiếng Việt thực hành & Nguyễn Thanh Thủy & TKC & $\begin{array}{l}\text { Các bình diện của từ và từ tiếng Việt / Đỗ Hữu } \\
\text { Châu. - H. : Đại Học Quốc Gia Hà Nội, 1997. - } 215 \\
\text { tr. ; } 21 \text { cm. }\end{array}$ & V172.12 & $0,1,2,3,4$ & $\mathrm{R}$ & \\
\hline
\end{tabular}




\begin{tabular}{|c|c|c|c|c|c|c|c|c|}
\hline 286 & Từ vựng Tiếng Việt thực hành & Nguyễn Thanh Thủy & TKC & $\begin{array}{l}\text { Từ vựng tiếng Việt / Nguyễn Công Đức, Nguyễn } \\
\text { Hữu Chương. - Tp. Hồ Chí Minh : Trường Đại học } \\
\text { Khoa học Xã họi và Nhân văn (Đại học Quốc gia } \\
\text { TP. Hồ Chí Minh), 2004. - } 191 \text { tr. }\end{array}$ & V172.12 & 4 & $\mathrm{R}$ & \\
\hline 287 & Từ vựng Tiếng Việt thực hành & Nguyễn Thanh Thủy & TKC & $\begin{array}{l}\text { Từ và nhận diện từ tiếng Việt / Nguyễn Thiện Giáp. - } \\
\text { H. : Giáo dục, } 1996 .-267 \text { tr. ; } 20 \text { cm. }\end{array}$ & V172.12-3 & 1 & $\mathrm{R}$ & \\
\hline 288 & Từ vựng Tiếng Việt thực hành & Nguyễn Thanh Thủy & TKC & $\begin{array}{l}\text { Từ tiếng Việt : hình thái - cấu trúc - từ láy - từ ghép - } \\
\text { chuyê̂n loại / Hoàng Văn Hành chủ biên ; Hà Quang } \\
\text { Năng, Nguyê̂n Văn Khang. - H. : Khoa học Xã hội, } \\
\text { 1998. - } 196 \text { tr. ; } 21 \text { cm. }\end{array}$ & V172.12-3 & $1,2,3,4$ & $\mathrm{C}$ & \\
\hline 289 & Từ vựng Tiếng Việt thực hành & Nguyễn Thanh Thủy & TKC & $\begin{array}{l}\text { Giáo trình cơ sở ngôn ngữ học và tiếng Việt / Bùi } \\
\text { Tất Tươm chủ biên ; Nguyễn Văn Bằng, Hoàng } \\
\text { Xuân Tâm. - Hà Nội : Giáo dục, 1997. - } 405 \text { tr. }\end{array}$ & V172.12 & & $\mathrm{R}$ & \\
\hline 290 & Lịch sử Tiếng Việt & Nguyễn Thị Hoàng Yến & & $\begin{array}{l}\text { Sự biến hóa của các âm tắc giữa (obstruentes } \\
\text { mediales) trong tiếng Việt / Ferlus M. - Tạp chí } \\
\text { Ngôn ngữ . - Số 2, 1981. }\end{array}$ & & & $\mathrm{R}$ & $\begin{array}{c}\text { Phòng Báo - Tạp } \\
\text { chí }\end{array}$ \\
\hline 291 & Lịch sử Tiếng Việt & Nguyễn Thị Hoàng Yến & & $\begin{array}{l}\text { Về sự phân loại các ngôn ngữ ở Đông nam châu Á / } \\
\text { Jakhontov S.E. - Tạp chí Ngôn ngữ. - Số 1, } 1991 .\end{array}$ & & & $\mathrm{C}$ & $\begin{array}{l}\text { Phòng Báo - Tạp } \\
\text { chí }\end{array}$ \\
\hline 292 & Lịch sử Tiếng Việt & Nguyễn Thị Hoàng Yến & & $\begin{array}{l}\text { Hai chữ B trong cuốn từ điển của A-lêch-xan đơ Rôt } \\
\text { / Haudricourt A.G. - Tạp chí Ngôn ngữ. - Số 4, } 1974\end{array}$ & & & $\mathrm{R}$ & $\begin{array}{l}\text { Phòng Báo - Tạp } \\
\text { chí }\end{array}$ \\
\hline 293 & Lịch sử Tiếng Việt & Nguyễn Thị Hoàng Yến & & $\begin{array}{l}\text { Vị trí của tiếng Vieêt trong các ngôn ngữ Nam Á / } \\
\text { Haudricourt A.G // Ngôn ngữ. - 1991. - Số } 1\end{array}$ & & & $\mathrm{R}$ & $\begin{array}{l}\text { Phòng Báo - Tạp } \\
\text { chí }\end{array}$ \\
\hline 294 & Lịch sử Tiếng Việt & Nguyễn Thị Hoàng Yến & & $\begin{array}{l}\text { Về nguồn gốc các thanh của tiếng Việt / Haudricourt } \\
\text { A.G. - Tạp chí Ngôn ngữ. - Số 1, } 1991\end{array}$ & & & $\mathrm{C}$ & $\begin{array}{c}\text { Phòng Báo - Tạp } \\
\text { chí }\end{array}$ \\
\hline 295 & Lịch sử Tiếng Việt & Nguyễn Thị Hoàng Yến & & $\begin{array}{l}\text { Giới hạn và nối kết của ngôn ngữ Nam Á ở Đông } \\
\text { Bắc / Haudricourt A.G. - Tạp chí Ngôn ngữ. - Số 1, } \\
1991\end{array}$ & & & $\mathrm{C}$ & \begin{tabular}{|c|}
$\begin{array}{c}\text { Phòng Báo - Tạp } \\
\text { chí }\end{array}$ \\
\end{tabular} \\
\hline
\end{tabular}




\begin{tabular}{|c|c|c|c|c|c|c|c|}
\hline 296 & Lịch sử Tiếng Việt & Nguyễn Thị Hoàng Yến & $\begin{array}{l}\text { Phương ngũ học tiếng Việt / Hoàng Thị Châu. - Hà } \\
\text { Nội. : Đại học Quốc gia Hà Nội, } 2009 .\end{array}$ & V172.12-5 & $1,2,3,4$ & $\mathrm{C}$ & \\
\hline 297 & Lịch sử Tiếng Việt & Nguyễn Thị Hoàng Yến & $\begin{array}{l}\text { Tìm hiểu tiếng Việt lịch sử / Nguyễn Ngọc San. - Tái } \\
\text { bản có bố sung, sứa chữa. - Hà Nội : Đại học Sư } \\
\text { phạm, 2003. - } 277 \text { tr. }\end{array}$ & V172.12 & & $\mathrm{R}$ & \\
\hline 298 & Lịch sử Tiếng Việt & Nguyễn Thị Hoàng Yến & $\begin{array}{l}\text { Giáo trình lịch sử ngữ âm tiếng Việt / Nguyễn Tài } \\
\text { Cẩn. - H. : Giáo dục, } 1997 .\end{array}$ & $\begin{array}{l}\text { V172.12- } \\
922 .\end{array}$ & $1,2,3,4$ & $\mathrm{R}$ & \\
\hline 299 & Lịch sử Tiếng Việt & Nguyễn Thị Hoàng Yến & $\begin{array}{l}\text { Thử phân kì } 12 \text { thế kỷ của tiếng Việt / Nguyễn Tài } \\
\text { Cẩn. - Tạp chí Ngôn ngữ. - Số 6, } 1998 \text {. }\end{array}$ & & & $\mathrm{C}$ & $\begin{array}{l}\text { Phòng Báo - Tạp } \\
\text { chí }\end{array}$ \\
\hline 300 & Lịch sử Tiếng Việt & Nguyễn Thị Hoàng Yến & $\begin{array}{l}\text { Nguồn gốc và quá trình hình thành cách đọc Hán - } \\
\text { Việt / Nguyễn Tài Cẩn. - H. : Đại học Quốc gia Hà } \\
\text { Nội, } 2000 \text {. }\end{array}$ & V171.11-0 & $0,1,2,4$ & $\mathrm{R}$ & \\
\hline 301 & Lịch sử Tiếng Việt & Nguyễn Thị Hoàng Yến & $\begin{array}{l}\text { Một số chứng tích về ngôn ngữ, văn tự và văn hoá / } \\
\text { Nguyễ̂n Tài Cẩn. - H. : Đại học Quốc gia, 2001. - } \\
439 \text { tr. ; } 20 \text { cm. }\end{array}$ & V100 & $1,2,3,4$ & $\mathrm{C}$ & \\
\hline 302 & Lịch sử Tiếng Việt & Nguyễn Thị Hoàng Yến & $\begin{array}{l}\text { Tiếng Việt và họ ngôn ngũ̃ Nam Á / Nguyễn Văn } \\
\text { Lợi. - Tạp chí Ngôn ngữ. - Số 4, 1990. - Tr. } 52 \text { - } 53 .\end{array}$ & & & $\mathrm{R}$ & $\begin{array}{l}\text { Phòng Báo - Tạp } \\
\text { chí }\end{array}$ \\
\hline 303 & Lịch sử Tiếng Việt & Nguyễn Thị Hoàng Yến & $\begin{array}{l}\text { Quá trình hình thành và sự đối lập âm vực thanh } \\
\text { điệu trong các ngôn ngữ Việt- Mường / Nguyễn Văn } \\
\text { Lợi. - Tạp chí Ngôn ngữ. - Số 1, } 1991 \text {. }\end{array}$ & & & $\mathrm{C}$ & $\begin{array}{l}\text { Phòng Báo - Tạp } \\
\text { chí }\end{array}$ \\
\hline 304 & Lịch sử Tiếng Việt & Nguyễn Thị Hoàng Yến & $\begin{array}{l}\text { Về sự phân loại nội bộ các ngôn ngữ của nhóm Việt- } \\
\text { Mường / N.K. Sokolovskaia. - Tạp chí Ngôn ngữ. - } \\
\text { Số 2, 1978. - Tr. } 49 \text { - 55. }\end{array}$ & & & $\mathrm{C}$ & $\begin{array}{l}\text { Phòng Báo - Tạp } \\
\text { chí }\end{array}$ \\
\hline 305 & Lịch sử Tiếng Việt & Nguyễn Thị Hoàng Yến & $\begin{array}{l}\text { Giáo trình lịch sử tiếng Việt : sơ thảo / Trần Trí } \\
\text { Dõi. - H. : Đại học quốc gia Hà Nội, 2005. - } 267 \text { tr. } \\
21 \mathrm{~cm} .\end{array}$ & $\begin{array}{c}\text { V172.12- } \\
\text { 0z7 }\end{array}$ & $0,1,2,3,4$ & $\mathrm{R}$ & \\
\hline
\end{tabular}




\begin{tabular}{|c|c|c|c|c|c|c|c|c|}
\hline 306 & Lịch sử Tiếng Việt & Nguyễn Thị Hoàng Yến & & $\begin{array}{l}\text { Tìm hiểu thêm về nguồn gốc thanh điệu tiếng Việt / } \\
\text { Trần Trí Dõi // Tiếng Việt và các ngôn ngữ Đông } \\
\text { Nam Á. - H., } 1988 .\end{array}$ & V172.12 & & $\mathrm{R}$ & \\
\hline 307 & Lịch sử Tiếng Việt & Nguyễn Thị Hoàng Yến & & http://en.wikipedia.org/wiki/Mon-Khmer_languages & & & $\mathrm{C}$ & \\
\hline 308 & Phong cách học tiếng Việt & Lê Thị Minh Hằng & GT & $\begin{array}{l}\text { Phong cách học thực hành tiếng Việt (dành cho sinh } \\
\text { viên nước ngoài) : bài giảng / Lê Thị Minh Hằn. - } \\
\text { TP. HCM. : Đại học Quốc gia, 2014. - } 176 \text { tr. ; } 21 \\
\text { cm. }\end{array}$ & V172.12-7 & $0,1,2,3,4$ & $\mathrm{C}$ & \\
\hline 309 & Phong cách học tiếng Việt & Lê Thị Minh Hằng & TKC & $\begin{array}{l}\text { Kỹ thuật và ngôn ngữ soạn thảo văn bản quản lý nhà } \\
\text { nước / Bùi Khắc Việt. - H. : Khoa học Xã hội, } 1997\end{array}$ & V09:S & 1.2 & 1998 & \\
\hline 310 & Phong cách học tiếng Việt & Lê Thị Minh Hằng & TKC & $\begin{array}{l}\text { Giáo trình co sở ngôn ngữ học và tiếng Việt / Bùi } \\
\text { Tất Tươm chủ biên ; Nguyễn Văn Bằng, Hoàng } \\
\text { Xuân Tâm. - Hà Nội : Giáo dục, 1997. - } 405 \text { tr. }\end{array}$ & V172.12 & & $\mathrm{R}$ & \\
\hline 311 & Phong cách học tiếng Việt & Lê Thị Minh Hằng & TKC & $\begin{array}{l}\text { Phong cách học tiếng Việt : giáo trình đào tạo giáo } \\
\text { viên Trung học cơ sở hệ cao đẳng sư phạm / Đinh } \\
\text { Trọng Lạc. - H. : Giáo dục, 2001. - } 204 \text { tr. ; } 20 \text { cm. }\end{array}$ & V172.12-7 & 2 & $\mathrm{C}$ & \\
\hline 312 & Phong cách học tiếng Việt & Lê Thị Minh Hằng & TKC & $\begin{array}{l}\text { Phong cách học tiếng Việt hiện đại / Hữu Đạt . - Hà } \\
\text { Nội. : Giáo dục Việt Nam, 2011 - } 435 \text { tr. ; } 21 \text { cm. }\end{array}$ & V172.12-7 & & $\mathrm{C}$ & TVTT \\
\hline 313 & Phong cách học tiếng Việt & Lê Thị Minh Hằng & TKC & $\begin{array}{l}\text { Hướng dẫn soạn thảo văn bản : những thủ tục hành } \\
\text { chính cần cho mọi công dân / Nguễên Đăng Dung } \\
\text { biên soạn. - Tp. Hồ Chí Minh : Nxb. TP. Hồ Chí } \\
\text { Minh, 1996. - } 493 \text { tr. ; } 20 \text { cm. }\end{array}$ & S621.03 & 0.2 & $\mathrm{R}$ & \\
\hline 314 & Văn học dân gian Việt Nam & Trần Thị Tươi & GT & Tập bài giảng do giảng viên soạn & & & $\mathrm{C}$ & GV cung cấp \\
\hline 315 & Văn học dân gian Việt Nam & Trần Thị Tươi & TKC & $\begin{array}{l}\text { Kho tàng truyện cổ tích Việt Nam / Nguyễn Đổng } \\
\text { Chi. - H. : Giáo dục, } 2000 \text {. }\end{array}$ & V3(1)-61 & 1,2 & $\mathrm{C}$ & \\
\hline
\end{tabular}




\begin{tabular}{|c|c|c|c|c|c|c|c|c|}
\hline 316 & Văn học dân gian Việt Nam & Trần Thị Tươi & TKC & $\begin{array}{l}\text { Văn học dân gian Việt Nam / Đinh Gia Khánh chủ } \\
\text { biên ; Chu Xuân Diên, Võ Quang Nhơn. - Tái bản } \\
\text { lần thứ mười hai. - H. : Giáo dục Việt Nam, 2009. - } \\
839 \text { tr. ; } 24 \mathrm{~cm} \text {. }\end{array}$ & V3(1)-6 & 1 & $\mathrm{R}$ & \\
\hline 317 & $\begin{array}{l}\text { Truyện ngắn Việt Nam hiện } \\
\text { dại }\end{array}$ & Nguyễn Thị Hoàng Yến & GT & $\begin{array}{l}\text { Giáo trình truyện ngắn Việt Nam hiện đại, Nguyễn } \\
\text { Thị Hòang Yến, Khoa Việt Nam học, KHXH\&NV } \\
\text { Tp.HCM (sẽ biên soạn). }\end{array}$ & & & $\mathrm{C}$ & \\
\hline 318 & $\begin{array}{l}\text { Truyện ngắn Việt Nam hiện } \\
\text { đại }\end{array}$ & Nguyễn Thị Hoàng Yến & TKC & $\begin{array}{l}\text { Văn học Việt Nam hiện đại nhận thức và thẩm định / } \\
\text { Vũ Tuấn Anh. - H. : Khoa học xã hội, 2001. - } 443 \\
\text { tr. ; } 21 \text { cm. }\end{array}$ & V5(1)7-30 & 1 & $\mathrm{R}$ & \\
\hline 319 & $\begin{array}{l}\text { Truyện ngắn Việt Nam hiện } \\
\text { đại }\end{array}$ & Nguyễn Thị Hoàng Yến & TKC & $\begin{array}{l}\text { Truyện ngắn Việt Nam : lịch sử - thi pháp - chân } \\
\text { dung / Phan Cự Đệ chủ biên. - H. : Giáo dục, 2007. - } \\
787 \text { tr. ; } 24 \text { cm. }\end{array}$ & V5(1)-334 & $0,1,2,3,4$ & $\mathrm{C}$ & \\
\hline 320 & $\begin{array}{l}\text { Truyện ngắn Việt Nam hiện } \\
\text { dại }\end{array}$ & Nguyễn Thị Hoàng Yến & TKC & $\begin{array}{l}\text { Nhìn lại tư tưởng văn nghệ thời Mỹ - Ngụy / Lê } \\
\text { Đình Ky. - Tp. Hồ Chí Minh : Nxb. Tp. Hồ Chí } \\
\text { Minh, 1987. - } 172 \text { tr. ; } 19 \text { cm. }\end{array}$ & V5(1)6-30 & $0,1,2,4$ & $\mathrm{C}$ & \\
\hline 321 & $\begin{array}{l}\text { Truyện ngắn Việt Nam hiện } \\
\text { đại }\end{array}$ & Nguyễn Thị Hoàng Yến & TKC & $\begin{array}{l}\text { Văn học Việt Nam sau } 1975 \text { những vấn đề nghiên } \\
\text { cứu và giảng dạy / Nguyễn Văn Long, Lã Nhâm } \\
\text { Thìn chủ biên. - H. : Giáo dục, 2006 }\end{array}$ & V5(1)6 & $0,1,2,3,4$ & $\mathrm{C}$ & \\
\hline 322 & Tiếng Việt Du lịch & Bùi Thị Phương Chi & GT & Tập bài giảng của giáo viên & & & $\mathrm{C}$ & GV cung cấp \\
\hline 323 & Tiếng Việt Du lịch & Bùi Thị Phương Chi & TKC & $\begin{array}{l}\text { Đất nước mến yêu. Kiến thức thuyết minh phục vụ } \\
\text { du lịch. Giáo trình Trường đào tạo nghiệp vụ du lịch } \\
\text { Sài gòn / Hiệp hội Du lịch TP. Hồ Chí Minh. - Tp. } \\
\text { Hồ Chí Minh : Nxb. Tp. Hồ Chí Minh, 1995. }\end{array}$ & $Đ 89(1) 0$ & $0,2,3$ & $\mathrm{C}$ & \\
\hline 324 & Tiếng Việt Du lịch & Bùi Thị Phương Chi & TKC & $\begin{array}{l}\text { Văn hóa làng xã : tín nguơơng, tục lệ \& hội làng / } \\
\text { Thùy Trang. - Hà Nội. : Thời Đại, 2009. - } 215 \text { tr. ; } \\
21 \text { cm. }\end{array}$ & U114(1) & $0,1,2,3,4$ & $\mathrm{C}$ & \\
\hline
\end{tabular}




\begin{tabular}{|c|c|c|c|c|c|c|c|c|}
\hline 325 & Tiếng Việt Du lịch & Bùi Thị Phương Chi & TKC & $\begin{array}{l}\text { Tổng quan du lịch : giáo trình dùng cho sinh viên } \\
\text { Đại học và Cao đẳng ngành Du lịch / Trần Nhoãn. - } \\
\text { Hà Nội : Trường Đại học Văn hóa Hà Nội, 2005. - } \\
196 \text { tr. }\end{array}$ & & & $\mathrm{R}$ & \\
\hline 326 & Tiếng Việt Du lịch & Bùi Thị Phương Chi & TKC & $\begin{array}{l}\text { Giáo trình văn hóa du lịch : dùng trong các trường } \\
\text { THCN / Lê Thị Vân chủ biên.. - H. : Hà Nội, } 2006\end{array}$ & U114(1) & $0,1,2,3,4$ & $\mathrm{C}$ & \\
\hline 327 & Tiếng Việt Du lịch & Bùi Thị Phương Chi & TKC & $\begin{array}{l}\text { Các website của các công ty du lịch, tổ chức du lịch } \\
\text { của nhà nước... }\end{array}$ & & & $\mathrm{C}$ & \\
\hline 328 & Tiếng Việt Du lịch & Bùi Thị Phương Chi & TKC & $\begin{array}{l}\text { Tư liệu khác: Các brochure, } \mathrm{VCD} \text {, quảng cáo quảng } \\
\text { bá du lịch của các quốc gia, các cơ quan họat động } \\
\text { trong lĩnh vực du lịch. }\end{array}$ & & & Internet & \\
\hline 329 & Du lịch Việt Nam & $\begin{array}{l}\text { ThS. Bùi Thị Phương } \\
\text { Chi }\end{array}$ & GT & $\begin{array}{l}\text { Tập bài giảng của giáo viên: DU LICH VIỆT NAM } \\
\text { do ThS Bủi Thị Phương Chi biên soạn tóm tắt từ } \\
\text { những tài liệu tham khảo dưới đây. }\end{array}$ & & & $\mathrm{C}$ & GV cung cấp \\
\hline 330 & |Du lịch Việt Nam & $\begin{array}{l}\text { ThS. Bùi Thị Phương } \\
\text { Chi }\end{array}$ & TK & $\begin{array}{l}\text { Về nội hàm Văn hoá du lịch / Bùi Thanh Thủy. - } \\
\text { Tạp chí Du lịch. Số 12, } 2009\end{array}$ & & & $\mathrm{C}$ & $\begin{array}{l}\text { Phòng báo - tạp } \\
\text { chí }\end{array}$ \\
\hline 331 & Du lịch Việt Nam & $\begin{array}{l}\text { ThS. Bùi Thị Phương } \\
\text { Chi }\end{array}$ & TK & $\begin{array}{l}\text { Những tác động kinh tế - xã hội của du lịch đối với } \\
\text { các dân tộc thiếu số ở Sa Pa / Lâm Mai Lan, Phạm } \\
\text { Mộng. - Tạp chí Dân tộc học. - Số 4, 2000. - Tr.34 - } \\
\text { 43. }\end{array}$ & & & $\mathrm{C}$ & $\begin{array}{l}\text { Phòng báo - tạp } \\
\text { chí }\end{array}$ \\
\hline 332 & Du lịch Việt Nam & $\begin{array}{l}\text { ThS. Bùi Thị Phương } \\
\text { Chi }\end{array}$ & TK & $\begin{array}{l}\text { Văn hóa - tài nguyên chủ yếu của du lịch Việt Nam / } \\
\text { Nguyễ̂n Thị Chiến. - Tạp chí Văn hóa nghệ thuật. - } \\
\text { Số } 5 \text { (227), 2003, tr. 23-27. }\end{array}$ & & & $\mathrm{C}$ & $\begin{array}{l}\text { Phòng báo - tạp } \\
\text { chí }\end{array}$ \\
\hline 333 & |Du lịch Việt Nam & $\begin{array}{l}\text { ThS. Bùi Thị Phương } \\
\text { Chi }\end{array}$ & TK & $\begin{array}{l}\text { Tổng quan du lịch : giáo trình dùng cho sinh viên } \\
\text { Đại học và Cao đẳng ngành Du lịch / Trần Nhoãn. - } \\
\text { Hà Nội : Trường Đại học Văn hóa Hà Nội, 2005. - } \\
196 \text { tr. }\end{array}$ & & & $\mathrm{R}$ & \\
\hline 334 & Du lịch Việt Nam & $\begin{array}{l}\text { ThS. Bùi Thị Phương } \\
\text { Chi }\end{array}$ & TK & $\begin{array}{l}\text { Giáo trình du lịch văn hóa. Những vấn đề lý luận và } \\
\text { nghiệp vụ / Trần Thúy Anh chủ biên. - H. : Giáo } \\
\text { dục, } 2011\end{array}$ & & & $\mathrm{C}$ & TVKHTH \\
\hline
\end{tabular}




\begin{tabular}{|c|c|c|c|c|c|c|c|}
\hline 335 & Du lịch Việt Nam & $\begin{array}{l}\text { ThS. Bùi Thị Phương } \\
\text { Chi }\end{array}$ & TK & $\begin{array}{l}\text { Giáo trình văn hóa du lịch : dùng trong các trường } \\
\text { THCN / Lê Thị Vân chủ biên.. - H. : Hà Nội, } 2006\end{array}$ & $\mathrm{U} 114(1)$ & $0,1,2,3,4$ & $\mathrm{C}$ \\
\hline 336 & Du lịch Việt Nam & $\begin{array}{l}\text { ThS. Bùi Thị Phương } \\
\text { Chi }\end{array}$ & TK & $\begin{array}{l}\text { Marketing du lịch / Robert Lanquar, Robert Hollier; } \\
\text { Đố Ngọc Hải dịch. - H. : Thế giới, 1992. - } 159 \text { tr. }\end{array}$ & $\begin{array}{c}\text { Q549+ } \\
\text { Q529.0- } \\
211.1 \\
\end{array}$ & $1,2,3,4$ & $\mathrm{C}$ \\
\hline 337 & Du lịch Việt Nam & $\begin{array}{l}\text { ThS. Bùi Thị Phương } \\
\text { Chi }\end{array}$ & TK & $\begin{array}{l}\text { Kinh tế du lịch / Robert Lanquar ; Phạm Ngọc Uyển } \\
\text { dịch. - H. : Thế giới, 2002. - } 148 \text { tr. }\end{array}$ & Q549 & $0,1,2,3,4$ & $\mathrm{C}$ \\
\hline 338 & Du lịch Việt Nam & $\begin{array}{l}\text { ThS. Bùi Thị Phương } \\
\text { Chi }\end{array}$ & Web & $\begin{array}{l}\text { http://www.dulichvietnam.com.vn - Tin tức du lịch } \\
\text { Việt Nam }\end{array}$ & & & $\mathrm{C}$ \\
\hline 339 & Du lịch Việt Nam & $\begin{array}{l}\text { ThS. Bùi Thị Phương } \\
\text { Chi }\end{array}$ & Web & $\begin{array}{l}\text { http://www.vietnamtourism.gov.vn/ - Tổng cuc du } \\
\text { lich Việt Nam }\end{array}$ & & & $\mathrm{C}$ \\
\hline 340 & Du lịch Việt Nam & $\begin{array}{l}\text { ThS. Bùi Thị Phương } \\
\text { Chi }\end{array}$ & Web & http://dulichvn.org.vn/ - Tổng cục du lịch Việt Nam & & & $\mathrm{C}$ \\
\hline 341 & Du lịch Việt Nam & $\begin{array}{l}\text { ThS. Bùi Thị Phương } \\
\text { Chi }\end{array}$ & Web & http://www.vita.vn/ - Hiêp hôi du lịch Viêt Nam & & & $\mathrm{C}$ \\
\hline 342 & Du lịch Việt Nam & $\begin{array}{l}\text { ThS. Bùi Thị Phương } \\
\text { Chi }\end{array}$ & Web & http://www.tapchidulich.com.vn/ & & & $\mathrm{C}$ \\
\hline
\end{tabular}

\section{CHÚ THÍCH: NOII LU'U TRŨ}

$\begin{array}{ll}\text { Kho } 0 & \text { Kho lưu } \\ \text { Kho } 1 & \text { Phòng đọc } 1-\text { Cơ sở } 1 \text { Đinh Tiên } \\ \text { Kho } 2 & \text { Phòng đọc } 2-\text { Cơ sở } 2 \text { Linh Trung } \\ \text { Kho } 3 & \text { Phòng mượn - Cơ sở } 1 \text { Đinh Tiên } \\ \text { Kho } 4 & \text { Phòng mượn - Cơ sở } 2 \text { Linh Tru } \\ \text { Đối với nguồn tài liệu tại các thư viện ngoài Thư viện } \\ \text { TVTT } & \text { Thư viện Trung tâm } \\ \text { TVKHTH } & \text { Thư viện Khoa học Tổng hợp } \\ \text { TVĐHM } & \text { Thư viện Đại học Mở } \\ \text { VTNMT } & \text { Viện tài Nguyên và Môi trường } \\ \text { TVĐHKTL } & \text { Đại học Kinh tế - Luật } \\ \text { TVĐHBK } & \text { Đại học Bách Khoa } \\ \text { TVĐHQT } & \text { Đại học Quốc tế }\end{array}$




\section{Tài liệu tham khảo:}

Đinh Gia Khánh, Bùi Duy Tân, Mai Cao Chương. (1978). Lịch sử văn học Việt Nam. Nxb Đại học \& Trung học chuyên nghiệp, Hà Nội.

Phạm Minh Chính, Vương Quân Hoàng. (2009). Kinh tế Việt Nam: Thăng trầm và đột phá. Nxb Chính trị Quốc gia, Hà Nội.

Trần Lê Bảo. (2008). Việt Nam học và nhập môn khu vực học. Nxb Giáo dục, Hà Nội. 